University of Nebraska - Lincoln

DigitalCommons@University of Nebraska - Lincoln

\title{
A Refined Pharmacophore Identifies Potent 4-Amino-7-chloroquinoline-Based Inhibitors of the Botulinum Neurotoxin Serotype A Metalloprotease
}

\author{
James C. Burnett \\ Dejan Opsenica \\ Kamaraj Sriraghavan \\ Rekha G. Panchal \\ Gordon Ruthel
}

See next page for additional authors

Follow this and additional works at: https://digitalcommons.unl.edu/usarmyresearch

Part of the Operations Research, Systems Engineering and Industrial Engineering Commons

Burnett, James C.; Opsenica, Dejan; Sriraghavan, Kamaraj; Panchal, Rekha G.; Ruthel, Gordon; Hermone, Ann R.; Nguyen, Tam L.; Kenny, Tara A.; Lane, Douglas J.; McGrath, Connor F.; Schmidt, James J.;

Vennerstrom, Jonathan L.; Gussio, Rick; Solaja, Bogdan A.; and Bavari, Sina, "A Refined Pharmacophore Identifies Potent 4-Amino-7-chloroquinoline-Based Inhibitors of the Botulinum Neurotoxin Serotype A Metalloprotease" (2007). US Army Research. 18.

https://digitalcommons.unl.edu/usarmyresearch/18

This Article is brought to you for free and open access by the U.S. Department of Defense at DigitalCommons@University of Nebraska - Lincoln. It has been accepted for inclusion in US Army Research by an authorized administrator of DigitalCommons@University of Nebraska - Lincoln. 


\section{Authors}

James C. Burnett, Dejan Opsenica, Kamaraj Sriraghavan, Rekha G. Panchal, Gordon Ruthel, Ann R. Hermone, Tam L. Nguyen, Tara A. Kenny, Douglas J. Lane, Connor F. McGrath, James J. Schmidt, Jonathan L. Vennerstrom, Rick Gussio, Bogdan A. Solaja, and Sina Bavari 


\title{
A Refined Pharmacophore Identifies Potent 4-Amino-7-chloroquinoline-Based Inhibitors of the Botulinum Neurotoxin Serotype A Metalloprotease
}

\author{
James C. Burnett, ${ }^{\dagger}$ Dejan Opsenica ${ }^{\ddagger}$ Kamaraj Sriraghavan, ${ }^{\S}$ Rekha G. Panchal, ${ }^{\dagger}$ Gordon Ruthel, ${ }^{\|}$Ann R. Hermone, ${ }^{\dagger}$ \\ Tam L. Nguyen, ${ }^{\dagger}$ Tara A. Kenny, ${ }^{\dagger}$ Douglas J. Lane, ${ }^{\dagger}$ Connor F. McGrath, ${ }^{\dagger}$ James J. Schmidt, ${ }^{\|}$Jonathan L. Vennerstrom, ${ }^{\S}$ \\ Rick Gussio, ${ }^{\perp}$ Bogdan A. Śolaja,,,$\#$ and Sina Bavari*,ll \\ SAIC-Frederick, Inc., Target Structure-Based Drug Discovery Group, Frederick, Frederick, Inc., National Cancer Institute at Frederick, \\ P.O. Box B, F.V.C. 310, Frederick, Maryland 21702, The Institute of Chemistry, Technology, and Metallurgy, Njegoševa 12, YU-11001 \\ Belgrade, Serbia, College of Pharmacy, 986025 University of Nebraska Medical Center, Omaha, Nebraska 68198, U.S. Army Medical \\ Research Institute of Infectious Diseases, Fort Detrick, 1425 Porter Street, Frederick, Maryland 21702, Developmental Therapeutics Program, \\ P.O. Box B, F.V.C. 310, NCI Frederick, Frederick, Maryland 21702, and Faculty of Chemistry, The University of Belgrade, Studentski trg 16, \\ P.O. Box 158, YU-11001 Belgrade, Serbia
}

Received December 19, 2006

\begin{abstract}
We previously identified structurally diverse small molecule (non-peptidic) inhibitors (SMNPIs) of the botulinum neurotoxin serotype A (BoNT/A) light chain (LC). Of these, several (including antimalarial drugs) contained a 4-amino-7-chloroquinoline (ACQ) substructure and a separate positive ionizable amine component. The same antimalarials have also been found to interfere with BoNT/A translocation into neurons, via $\mathrm{pH}$ elevation of the toxin-mediated endosome. Thus, this structural class of small molecules may serve as dualfunction BoNT/A inhibitors. In this study, we used a refined pharmacophore for BoNT/A LC inhibition to identify four new, potent inhibitors of this structural class $\left(\mathrm{IC}_{50}\right.$ 's ranged from 3.2 to $\left.17 \mu \mathrm{M}\right)$. Molecular docking indicated that the binding modes for the new SMNPIs are consistent with those of other inhibitors that we have identified, further supporting our structure-based pharmacophore. Finally, structural motifs of the new SMNPIs, as well as two structure-based derivatives, were examined for activity, providing valuable information about pharmacophore component contributions to inhibition.
\end{abstract}

\section{Introduction}

Botulinum neurotoxins $(\mathrm{BoNTs})^{a}$ are the most potent of the biological toxins; the lethal dose of BoNT serotype A (BoNT/ A) is estimated to be between 1 and $5 \mathrm{ng} \mathrm{kg}^{-1}$ for humans. ${ }^{1,2}$ As a result, these enzymes, which are responsible for the paralysis associated with botulism, are listed as category A (highest priority) biothreat agents by the Centers for Disease Control and Prevention (CDC). BoNTs are easily produced and may be delivered via food "spiking" and/or aerosol route. ${ }^{2-6}$ Furthermore, as BoNTs are now used to treat a range of medical conditions, and in many cosmetic applications,, $3-14$ they are being produced in increasing quantities, making their misuse, accidental overdosing, and/or instances of adverse side effects ${ }^{15}$ more likely. Neither the currently available CDC BoNT equine antitoxins, which can cause adverse anaphylaxis and serum sickness, ${ }^{16}$ nor experimental antibodies can counter these enzymes once they are inside neurons. Furthermore, BoNT intoxication can occur rapidly, ${ }^{17}$ and individuals who have been maliciously exposed to a BoNT(s), or have received an accidental overdose, will most likely seek medical attention only after clinical symptoms (i.e., muscle paralysis) manifest. At this time, critical care mechanical ventilation is the only life-saving

* To whom correspondence should be addressed. (B.A.S.) Phone: $(+381-$ 11) 638-606. Fax: (+381-11) 638-061. E-mail: bsolaja@chem.bg.ac.yu. (S.B.) Phone: (301) 619-4246. Fax: (301) 619-2348. E-mail: sina.bavari@us.army.mil.

National Cancer Institute at Frederick.

$\doteqdot$ The Institute of Chemistry, Technology, and Metallurgy.

$\S$ University of Nebraska Medical Center.

" U.S. Army Medical Research Institute of Infectious Diseases.

${ }^{\perp}$ Developmental Therapeutics Program.

\# The University of Belgrade.

a Abbreviations: BoNTs, botulinum neurotoxins; BoNT/A, botulinum neurotoxin serotype A; BoNT/A LC, BoNT/A light chain; SMNPIs, small molecule (non-peptidic) inhibitors; ACQ, 4-amino-7-chloroquinoline. option once diaphragm muscles cease to function. Yet, the effects of internalized BoNTs can last for weeks, ${ }^{18,19}$ rendering such medical care impractical for wide scale application. By comparison, small molecule (non-peptidic) inhibitors (SMNPIs) could serve as post-intoxication "rescue" therapeutics and prophylactics.

There are seven known BoNT serotypes (identified as A-F). Each cleaves a component of the SNARE (soluble $N$-ethylmaleimide-sensitive factor attachment protein receptor) complex, ${ }^{20,21}$ which facilitates the transport of acetylcholine into neuromuscular junctions. BoNT serotypes $\mathrm{A}$ and $\mathrm{E}$ cleave SNAP-25 (synaptosomal-associated protein $(25 \mathrm{kDa})$ ), ${ }^{22}$ serotypes B, D, F, ${ }^{23}$ and $\mathrm{G}$ cleave VAMP (vesicle-associated membrane protein),${ }^{24-27}$ and serotype $\mathrm{C} 1$ cleaves both SNAP25 and syntaxin 1.28

X-ray crystal structures of BoNT holotoxins ${ }^{29,30}$ show that these enzymes are composed of a heavy chain (HC) and a light chain (LC), which, following post-translational modification, are connected by a disulfide bridge. ${ }^{29}$ The LC is a zinc metalloprotease. The $\mathrm{HC}$ transports the $\mathrm{LC}$ into the neuronal cytosol via an acidic endosome.

In a previous publication, ${ }^{31}$ we identified a range of novel, structurally diverse, non-zinc chelating SMNPIs of the BoNT/A LC. In particular, we showed that several compounds containing the weakly basic $\left(\mathrm{p} K_{\mathrm{a}} \approx 8\right)$ ACQ substructure and a separate ionizable amine component were among the most potent of the inhibitors. ${ }^{31}$ Additionally, we proposed binding modes for the compounds and developed a common pharmacophore for BoNT/A LC inhibition. ${ }^{31}$ In a subsequent molecular dynamics study, we demonstrated that conformationally flexible loops surrounding the BoNT/A LC substrate binding cleft may reorient to decrease the solvent accessibility of the cleft (as compared to respective energy refined structures), while simultaneously providing more hydropathically feasible binding contacts for 
SMNPIs. ${ }^{32}$ The molecular dynamics studies were pivotal for identifying a binding mode $^{33}$ for the potent pseudo-peptide inhibitor 2-mercapto-3-phenylpropionyl-RATKML (mpp-RAT$\mathrm{KML}, K_{\mathrm{i}}=330 \mathrm{nM}^{34}$ ). In the same study, we also proposed new pharmacophore components and constraints based on the docked model of mpp-RATKML, and, using this information, we identified more potent SMNPIs. ${ }^{33}$ In this study, we build on our previous work by describing how the refined pharmacophore $^{33}$ was used to discover new small molecule inhibitors possessing the ACQ substructure and a separate ionizable, aliphatic amine component.

\section{Results and Discussion}

Based on the identification of $N, N$-bis(7-chloroquinolin-4yl)diamines and five antimalarial drugs (amodiaquine, chloroquine, quinacrine, quinidine, and quinine) as SMNPIs of the BoNT/A LC, ${ }^{31}$ we have continued to pursue the identification of new inhibitors of this structural class possessing the weakly basic ACQ substructure and an ionizable amine; both of these components have been found to be key to activity. ${ }^{31}$ Further supporting this approach are the findings of Deshpande et al..$^{35}$ and Sheridan et al., ${ }^{36}$ demonstrating that ACQ-based drugs, which also possess a separate ionizable nitrogen atom (e.g., amodiaquine), delay BoNT/A induced muscle paralysis. In those studies, it was hypothesized that the compounds act by interfering with toxin translocation, most likely by increasing the $\mathrm{pH}$ of the toxin-mediated endosome. ${ }^{35,36}$ This is a logical supposition as ACQ antimalarials have been shown to target and increase the $\mathrm{pH}$ of the acidic food vacuole of Plasmodium falciparum. ${ }^{37-39}$ However, neither of the earlier studies reported LC inhibition in vitro. As indicated above, we demonstrated that several of the same antimalarials also directly inhibit BoNT/A LC metalloprotease activity ${ }^{31}$ however, they do so at higher concentrations than reported in the muscle twitch assays used in the earlier studies. ${ }^{35,36}$ This comparison indicates that the observed muscle twitch inhibition could not have resulted solely from inhibition of the enzyme's LC. Thus, the Deshpande et al..$^{35}$ and Sheridan et al. ${ }^{36}$ data, in combination with our previous findings, indicate that such molecules may serve as dual-function countermeasures, acting both as translocation inhibitors and directly against the metalloprotease activity of the LC.

A Refined Pharmacophore Is Used To Identify New BoNT/A LC Inhibitors Possessing Both the ACQ Substructure and a Separate Ionizable Amine. The first step in identifying new SMNPIs was to use a recently refined/expanded pharmacophore for BoNT/A LC inhibition ${ }^{33}$ (Figure 1A) to evaluate diverse target compounds possessing the ACQ substructure. It is important to note that the eight-component pharmacophore model presented in Figure 1A is a logical extension of the six-component model shown in our original work $^{31}$ and is part of an ongoing refinement of our pharmacophore for BoNT/A LC inhibition ${ }^{32,33}$ (which is occurring as more data become available). In this study, we wanted to identify compounds containing as many pharmacophore features as possible, but with the following specific components: (1) the ACQ substructure (which incorporates pharmacophore components $\mathrm{A}$, a heteroatom associated with $\mathrm{A}$, and $\mathrm{C}$ (Figure 1A)), (2) an ionizable amine located 6.5-9.5 from the centroid of the ACQ (pharmacophore component E (Figure 1A)), and (3) at least one of the new components from our expanded pharmacophore, either $\mathrm{F}^{33}$ (a positive ionizable moiety located 11.7-16.7 $\AA$ from the quinoline centroid) or $\mathrm{G}^{33}$ (a hydrophobic moiety located 8.5-12.5 ̊ from the quinoline centroid) (Figure 1A). Subsequently, a congeneric series of 4-amino-7-chloro-
A

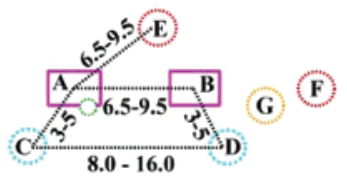

Additional Distances

$A-F=11.7-16.7$

$A-G=8.5-12.5$

B

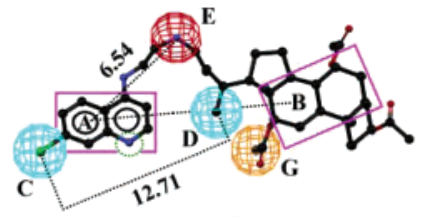

$A-B=12.14$

$A-C=4.25$

$A-G=9.05$

$\mathrm{B}-\mathrm{D}=\mathbf{5 . 8 6}$

B - $\mathbf{G}=\mathbf{5 . 6 3}$
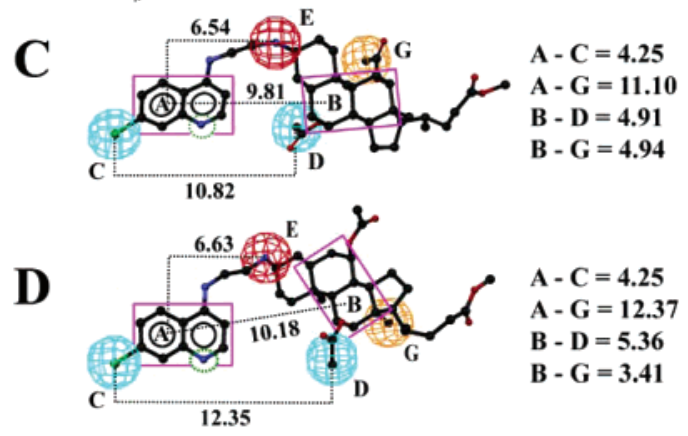

$\mathbf{E}$

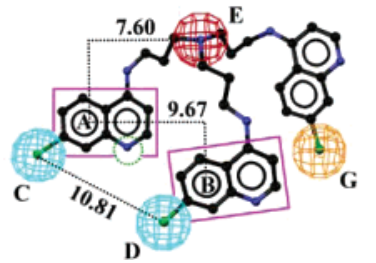

$A-C=4.25$

$A-G=10.84$

$B-D=4.25$

$B-G=4.75$

Figure 1. Pharmacophore mapping to inhibitors 1-4. (A) The refined/ expanded pharmacophore for BoNT/A LC inhibition. Planar components A and B are magenta rectangles. The dashed, green circle in plane A represents a heteroatom. Hydrophobic components $\mathrm{C}$ and $\mathrm{D}$ are shown as dashed, light blue circles. The positive ionizable pharmacophore component $\mathrm{E}$ is shown as a dashed, red circle. New pharmacophore component $\mathrm{F}^{33}$ also a positive ionizable moiety, is shown as a dashed red circle, while new hydrophobic pharmacophore component $\mathrm{G}$ is a dashed orange circle. (B, C, D, and E) Mapping of inhibitors 1-4, respectively, to the expanded pharmacophore. Distances between components are in angstroms. Pharmacophore component colors are as indicated in (A).

quinoline-cholate-acetates, $\mathbf{1 - 3}$, and a tri-ACQ derivative, $\mathbf{4}$, were identified (see Scheme 1 for two-dimensional (2-D) structures of 1-3 and Figure 2 for the 2-D structure of 4).

Pharmacophore mapping to 1-4 indicated that in each case ACQ is plane A (Figure 1B-E), and the quinoline ring nitrogen is the heteroatom associated with this plane. For $\mathbf{1 - 3}$, component $\mathrm{B}$ is the central decahydronapthalene of the methyl cholate acetate (rings $\mathrm{B}$ and $\mathrm{C}$ according to steroid ring designation) (Figure $1 \mathrm{~B}-\mathrm{D}$ ), while in $\mathbf{4}$ it is a second ACQ (Figure 1E). Hydrophobic component $\mathrm{C}$ is the 7-chloro substituent of the plane A ACQ for all inhibitors (Figure 1B-E), and pharmacophore component D is a methyl for $\mathbf{1}$ (Figure 1B), an acetyl group for $\mathbf{2}$ and $\mathbf{3}$ (Figure $1 \mathrm{C}$ and $\mathrm{D}$ ), and a chloro substituent for 4 (Figure 1E).

As a second specific criterion, each of the molecules contains a separate ionizable, aliphatic amine (Figure 1B-E), which corresponds to pharmacophore component E (Figure 1A). Finally, all of the molecules possess hydrophobic pharmacophore component $\mathrm{G}$ from the expanded/refined pharmacophore ${ }^{33}$ (Figure 1A) (the third specified criterion, see above), which is an acetyl group for $\mathbf{1}$ and $\mathbf{2}$ (Figure 1B and C), a methyl group for 3 (Figure 1D), and a chloro substituent for 4 (Figure 1E). 
Scheme $1^{a}$

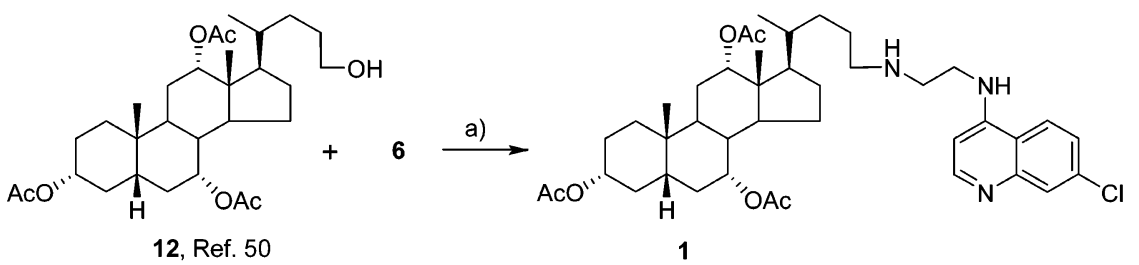

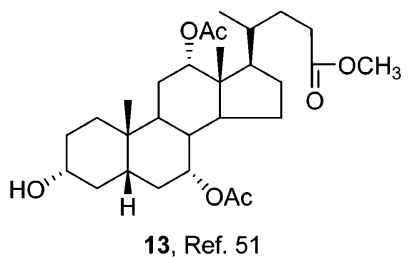

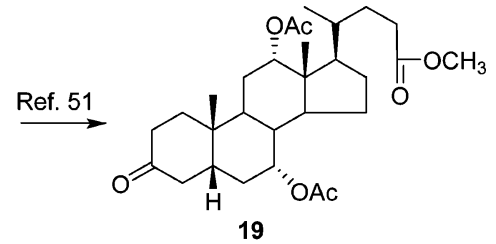

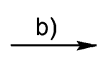<smiles>C=C(/C=C/C)NCCNCCNc1ccnc2cc(Cl)ccc12</smiles><smiles>[3H]C</smiles>

c)

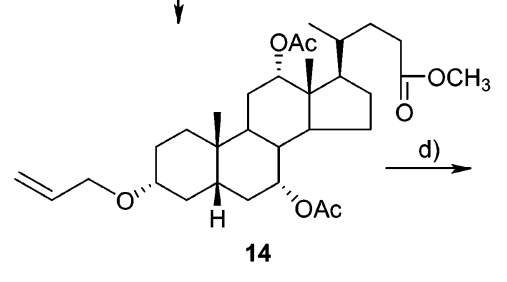<smiles>CCCCCCCCCCCC</smiles>

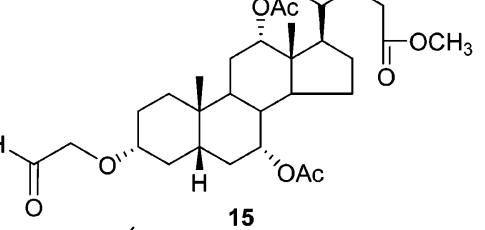

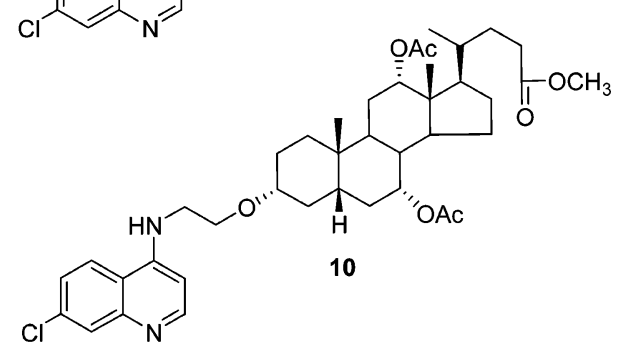

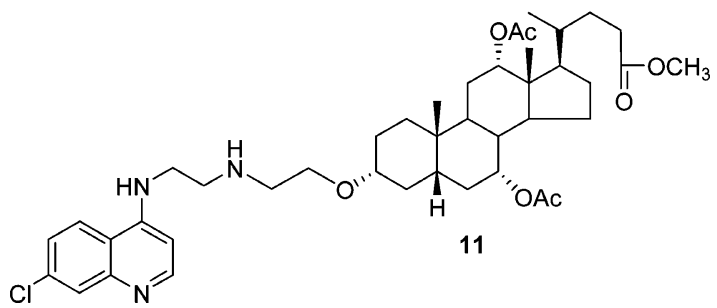
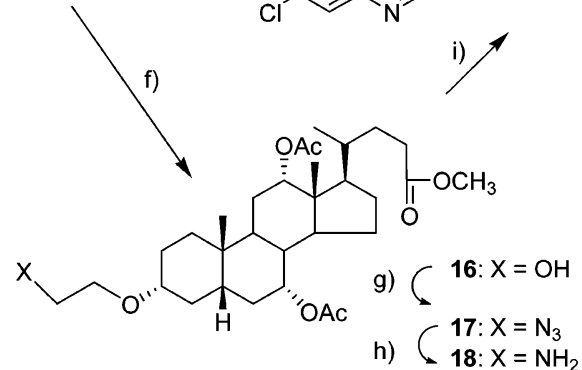

${ }^{a}$ Reagents and conditions: (a) (i) $\mathrm{MsCl}$, pyridine; (ii) 6, DMF; (b) 6, $\mathrm{NaBH}_{3} \mathrm{CN}, \mathrm{CH}_{3} \mathrm{CN}$; (c) allyl bromide, ${ }^{i} \mathrm{Pr}_{2} \mathrm{NEt}, \mathrm{NMP}, 80{ }^{\circ} \mathrm{C}$; (d) (i) $\mathrm{O}_{3}, \mathrm{MeOH},-78$ ${ }^{\circ} \mathrm{C}$; (ii) $\mathrm{Me}_{2} \mathrm{~S}$; (e) 6, $\mathrm{NaBH}(\mathrm{OAc})_{3}, \mathrm{CH}_{2} \mathrm{Cl}_{2}$; (f) $\mathrm{NaBH}(\mathrm{OAc})_{3}, \mathrm{CH}_{2} \mathrm{Cl}_{2}$; (g) (i) $\mathrm{MsCl}$, pyridine; (ii) $\mathrm{NaN}_{3}, \mathrm{DMF}$; (h) $\mathrm{PPh}_{3}, \mathrm{THF}, \mathrm{H}_{2} \mathrm{O}, 50{ }^{\circ} \mathrm{C}$; (i) $4,7-$ dichloroquinoline, $\mathrm{PhOH}, 120^{\circ} \mathrm{C}$.<smiles></smiles><smiles>[R]Nc1ccnc2cc(Cl)ccc12</smiles>

$5, \mathrm{R}=\mathrm{H}$ 6, $\mathrm{R}=\left(\mathrm{CH}_{2}\right)_{2} \mathrm{NH}_{2}$ $7, \mathrm{R}=\left(\mathrm{CH}_{2}\right)_{3} \mathrm{NH}_{2}$

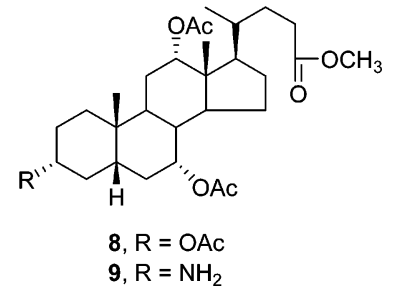

Figure 2. Two-dimensional structures of 4-9.

As observed in Figure 1B-E, 1-4 all show a good fit with respect to the distance constraints specified by the pharmacophore.

In Vitro Testing. Compounds $\mathbf{1}-\mathbf{3}$ were initially examined for percent inhibition of the BoNT/A LC at $50 \mu \mathrm{M}$ concentrations, while 4 was tested at a $20 \mu \mathrm{M}$ concentration. Results from these initial analyses indicated $90 \%$ enzyme inhibition by $\mathbf{1}$ and $\mathbf{3}, 80 \%$ inhibition by $\mathbf{2}$, and $67 \%$ inhibition by $\mathbf{4}$. Subsequent determination of $\mathrm{IC}_{50}$ values revealed that SMNPIs $\mathbf{1 - 4}$ are
Table 1. Inhibitory Potencies of 1-4

\begin{tabular}{cc}
\hline SMNPI & $\mathrm{IC}_{50}{ }^{a}(\mu \mathrm{M})$ \\
\hline $\mathbf{1}$ & $10( \pm 0.80)$ \\
$\mathbf{2}$ & $17( \pm 1.7)$ \\
$\mathbf{3}$ & $7.0( \pm 1.0)$ \\
$\mathbf{4}$ & $3.2( \pm 0.92)$ \\
\hline
\end{tabular}

${ }^{a} \mathrm{IC}_{50}$ values for the SMNPIs were calculated from plots of concentration versus inhibition (see Experimental Section for details). Results are the averages of duplicate determinations.

among the most potent inhibitors of the BoNT/A LC reported to date, ${ }^{33,40-42}$ possessing $\mathrm{IC}_{50}$ values ranging from 3.2 to 17.0 $\mu \mathrm{M}$ (Table 1). In agreement with structurally distinct SMNPIs reported by our research group (possessing $K_{\mathrm{i}}$ values ranging from 3.0 to $10.0 \mu \mathrm{M}^{33}$ ), compounds $\mathbf{1 - 4}$ demonstrate that our strategy of incorporating new pharmacophore features (i.e., pharmacophore components $\mathrm{F}$ or $\mathrm{G}),{ }^{33}$ in addition to original components, ${ }^{31,32}$ results in the identification of more potent inhibitors.

Molecular Docking of SMNPIs 1-4 Demonstrates a Consistency with Previous Inhibitor Binding Modes, Reinforcing Our Structure-Based Pharmacophore Approach. Compounds 1-4 were docked in the BoNT/A LC substrate binding cleft to determine if they would also engage in intermolecular contacts that were comparable to those predicted for other structurally diverse SMNPIs. ${ }^{31-33}$ Similar to our previously docked models of ACQ inhibitors, ${ }^{31,32}$ the 7-chloro 

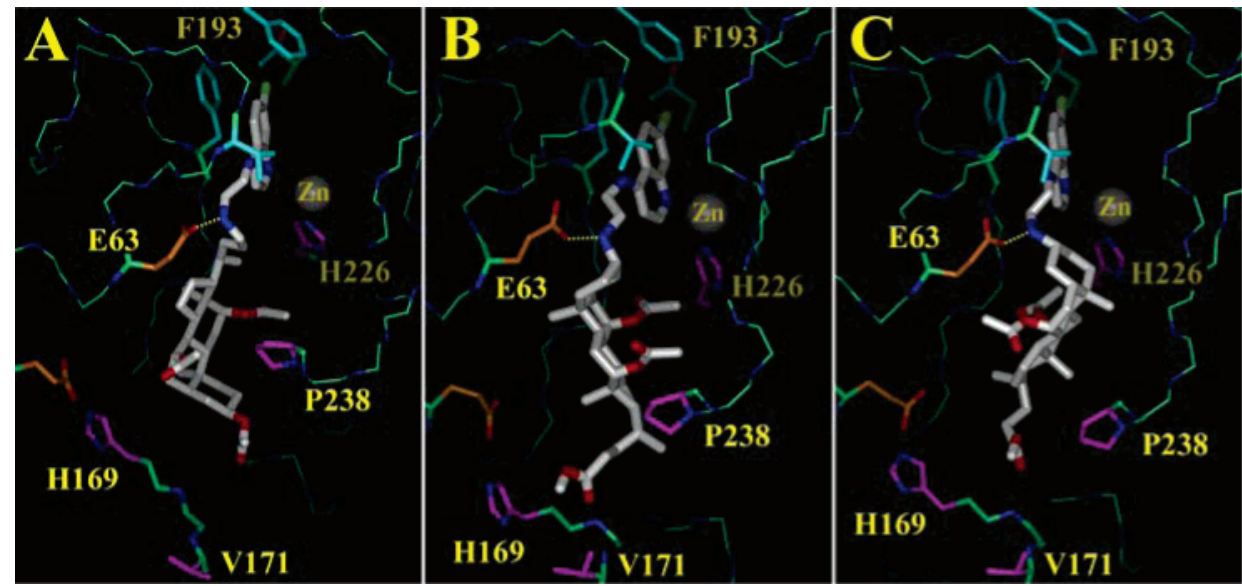

Figure 3. Docked models of SMNPIs 1-3. Inhibitors are depicted in thicker stick with white carbons. Carbons of binding subsite 1 residues are cyan, of binding subsite 2 are magenta, and of the polar contact region are orange. All other carbons are green. Oxygen atoms are red, and nitrogen atoms are blue. The yellow dashed line indicates a hydrogen bond. (A, B, and C) Docked models of SMNPIs 1, 2, and 3, respectively.
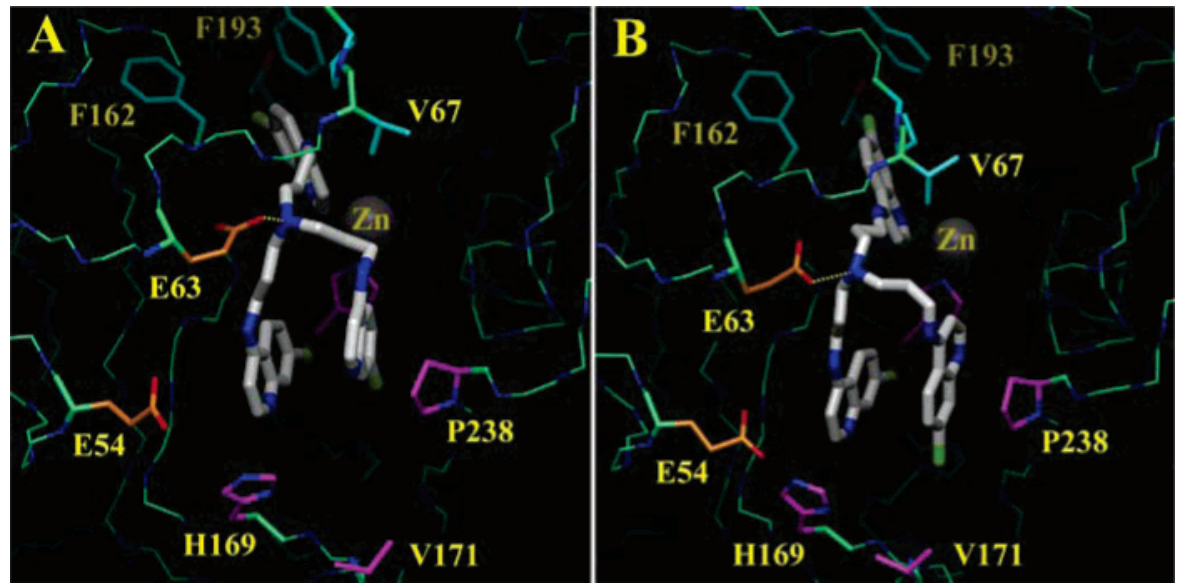

Figure 4. $\pi$ stacking by two of the quinoline rings of SMNPI 4 results in two feasible binding modes. Colors, stick thicknesses, and dashed lines are as indicated in Figure 3. (A) The inhibitor docked with the chloro substituents of the $\pi$ stacking quinoline rings facing into the substrate binding cleft. (B) An alternative binding mode with one of the $\pi$ stacking quinolines oriented in the opposite direction.

substituents of $\mathbf{1 - 3}$ (Figure $3 \mathrm{~A}-\mathrm{C}$ ) and one of the ACQs of 4 (Figure 4A and B) engage in favorable hydrophobic contacts with residues Phe 162, Phe 163, and Thr 219 of hydrophobic binding subsite $1^{31-33}$ (also described as the $\mathrm{S} 1^{\prime}$ binding site ${ }^{34}$ ). At the same time, the quinoline nitrogens of the inhibitors are positioned so that this heteroatom may interfere with the enzyme's catalytic engine. This same heteroatom:catalytic engine perturbation has been a consistent theme in the docked models of described SMNPIs, including those in which pharmacophore plane $\mathrm{A}$ is an indolyl/benzofuranyl, ${ }^{31-33}$ as well as those possessing the ACQ substructure. ${ }^{31}$

Linker methylenes of $\mathbf{1 - 4}$ engage in favorable hydrophobic collapse with the side chain methylenes of Lys 65, and the hydrophobic side chains of Val 67 and Pro 68 (Figure 3A-C; Figure $4 \mathrm{~A}$ and $\mathrm{B}$ ). These residues are part of a flexible loop (LC residues 48-78, referred to as loop 1 for the remainder of the text) that reorients toward the enzyme's substrate binding cleft during molecular dynamics analysis. ${ }^{32,33}$ As in our previous reports, ${ }^{32,33}$ this loop reorientation, in addition to providing favorable new inhibitor contacts, also provides solvent shielding for SMNPIs. This is clearly observed in Figure $3 \mathrm{~A}-\mathrm{C}$ and Figure 4A and $\mathrm{B}$, as loop 1 residues are located directly above atoms linking the ACQ and cholate-acetate components of $\mathbf{1 - 3}$, and two of the ACQs of 4.

The secondary nitrogens of $\mathbf{1 - 3}$, and the tertiary nitrogen of 4, engage in hydrogen bonds with the side chain carboxylate of Glu 63, a residue located in a polar contact region of the substrate binding cleft (Figure $3 \mathrm{~A}-\mathrm{C}$; Figure $4 \mathrm{~A}$ and B). ${ }^{31-33}$ This intermolecular hydrogen bond is also consistent with our docked model of mpp-RATKML, ${ }^{33}$ in which the Arg side chain guanidinium is predicted to engage in a hydrogen bond with the Glu 163 side chain carboxylate.

The steroidal components of $\mathbf{1 - 3}$, in addition to occupying a significant volume of the LC substrate cleft, also serve as rigid platforms for positioning key pharmacophore components in binding subsite $2 .{ }^{31-33}$ For SMNPI 1, the C20 methyl group occupies steric space in the substrate cleft that is located directly behind His 226 and adjacent to Cys 164 (Figure 3A). For inhibitors $\mathbf{2}$ and 3, this same space is occupied by $7 \alpha$-acetyl (Figure 3B) and 12 $\alpha$-acetyl (Figure 3C) substituents, respectively, while a second chloro substituent from SMNPI 4 occupies this space (Figure 4A and B). In each case, the binding modes of the methyl, acetyl, and chloro substituents are consistent with similar cleft occupancy observed for hydrophobic chloro, methyl, and methoxy substituents in the docked models of other, structurally diverse, SMNPIs. ${ }^{31-33}$

The $7 \alpha$ - and $12 \alpha$-acetyl substituents of SMNPIs $\mathbf{1}$ and 2, respectively, pack behind Pro 238 (Figure 3A and B), while the same steric space is occupied by the $\mathrm{C} 13$ methyl group of 3 (Figure 3C), and a third ACQ of SMNPI 4 (Figure 4A and B). Moreover, two potential binding modes were identified for SMNPI 4. Specifically, we found that intramolecular $\pi$ stacking between two of the three ACQ quinoline rings reinforces the stability of the predicted binding modes by significantly 
decreasing the conformational freedom of the inhibitor. In the first binding mode (Figure 4A), hydrophobic packing near Pro 238 is achieved with the ACQ chloro substituent oriented into the substrate cleft, while in the second binding mode (Figure 4B) it is achieved with the chloro substituent facing the opposite direction.

For SMNPIs 1-4, favorable hydrophobic interactions with the Pro 238 side chain are consistent with those observed for the Met residue of the docked model of mpp-RATKML. ${ }^{33}$ Indeed, the hydrophobic contacts between the mpp-RATKML Met and the side chain of Pro 238 were used to derive component $\mathrm{G}$ of the refined/expanded pharmacophore (Figure 1A). ${ }^{33}$ Of significance to this study is the observation that the predicted binding modes of $\mathbf{1 - 4}$ indicate that the $\mathrm{G}$ component adds an additional hydrophobic anchor and, in doing so, results in improved substrate cleft complementarity.

Inhibitors $\mathbf{1 - 3}$ also resemble the docked model of mppRATKML in that the $3 \alpha$-acetyl substituent of $\mathbf{1}$ and the C23 substituents of both $\mathbf{2}$ and $\mathbf{3}$ all dock so that a methyl moiety points toward and engages in favorable contacts with the side chain of Val 171, which is located in flexible loop 2 (residues 167-180) at the lower edge of the binding cleft (with respect to the orientation of the enzyme in Figure $3 \mathrm{~A}-\mathrm{C}$ ). However, it is important to note that, while pharmacophore components of the SMNPIs share similar binding site contacts with corresponding components of mpp-RATKML, the unique, optimized steric occupancy achieved by the pseudo-peptide, ${ }^{34}$ as compared to the identified SMNPIs, is reflected in the fact that it is still the most potent inhibitor of the BoNT/A LC reported to date. ${ }^{33}$ Unfortunately, our ability to completely take advantage of this novel steric space is limited. This is due to a lack of steric congruency between the way in which the optimized pseudopeptide inhibitor ${ }^{34}$ populates the BoNT/A LC substrate binding cleft and the positions on the SMNPIs where substituents can be added or modified.

Finally, inhibitor $\mathbf{4}$ also occupies additional steric volume in the substrate binding cleft (as compared to previously identified SMNPIs ${ }^{31}$ ); in both of its proposed binding modes (Figure 4A and B), one of the inhibitor's ACQ's packs behind His 169 (which is a residue of loop 2 that sits adjacent to Val 171 in the three-dimensional structure of the enzyme).

The Effects of Inhibitor Structural Motifs and Derivatives on BoNT/A LC Metalloprotease Activity: Pharmacophore Component E Dominates Potency for This Structural Class. The final analyses of this study involved determining the importance of the structural components of $\mathbf{1 - 4}$ to BoNT/A LC inhibition. To start, ACQ (4-amino-7-chloroquinoline, 5, Figure 2), the smallest substructure common to the SMNPIs, possessing pharmacophore component A, a heteroatom associated with this plane, and component $\mathrm{C}$ (Figure 1A), was evaluated. The rationale for examining $\mathbf{5}$ was to determine if two or more ACQs might simultaneously bind in the substrate cleft, similar to the docked model of inhibitor 4 (but without the need for a central linker). However, examination of this substructure in our assay resulted in only $12 \%$ inhibition at a concentration of $50 \mu \mathrm{M}$ (Table 2). Hence, while ACQ is a key component of molecules in this inhibitor class, it must be coupled with additional pharmacophoric features to achieve appreciable potency.

The above results prompted a question: would incorporating atoms of the flexible linkers of $\mathbf{1 - 4}$, along with pharmacophore component E, increase the potency of ACQ? Again, the smallest structural denominators of the inhibitors were examined. For 1-3, the substructure was $N^{1}$-(7-chloroquinolin-4-yl)-ethane-
Table 2. Inhibitory Potencies of 5-11

\begin{tabular}{cc}
\hline compound & $\begin{array}{c}\% \text { inhibition }^{a} \\
(50 \mu \mathrm{M})\end{array}$ \\
\hline $\mathbf{5}$ & 12 \\
$\mathbf{6}$ & 33 \\
$\mathbf{7}$ & 22 \\
$\mathbf{9}$ & 0 \\
$\mathbf{1 0}$ & 13 \\
$\mathbf{1 1}$ & 9 \\
\end{tabular}

\footnotetext{
${ }^{a}$ Percent inhibition measurements were performed in duplicate, and in
} all cases standard deviations were less than $\pm 25 \%$.

1,2-diamine (6, Figure 2), which was found to inhibit the BoNT/A LC by $33 \%$ at $50 \mu \mathrm{M}$ concentration (Table 2); for $\mathbf{4}$, the substructure was $N^{1}$-(7-chloroquinolin-4-yl)-propane-1,3diamine (7, Figure 2), which inhibited the enzyme by $22 \%$ at $50 \mu \mathrm{M}$ concentration (Table 2). On the basis of our docked models, we hypothesize that the increase in activity for $\mathbf{6}$ and 7 (over that of 5) results from a hydrogen bond with an acidic residue in the polar contact region (presumably Glu 63). Moreover, our models also predict that the side chain methylenes of $\mathbf{6}$ and $\mathbf{7}$ may desolvate under hydrophobic residues of loop 1, with the slightly lower potency of 7 most likely resulting from a higher entropic binding penalty.

Focus was next placed on the methyl cholate acetate component (8, Figure 2) of SMNPIs $\mathbf{1 - 3}$, which incorporates pharmacophoric features B, C, and G (Figure 1B-D). Because of its rigidity and bulk, it was hypothesized that $\mathbf{8}$ alone might demonstrate a moderate degree of inhibition; however, when examined at a $50 \mu \mathrm{M}$ concentration against the BoNT/A LC, it was inactive (Table 2). Thus, the steroidal motif alone cannot effectively populate the enzyme's substrate binding cleft in the absence of the ACQ and/or ionizable amine moieties. To determine if incorporating pharmacophore component $\mathrm{E}$ might transform 8 into an inhibitor, the $3 \alpha$-acetyloxy group of this molecule was replaced with an ionizable $3 \alpha-\mathrm{NH}_{2}$ substituent (9, Figure 2), effectively creating a substructure of SMNPI 3 (Scheme 1), the most potent molecule of the ACQ-cholate acetate congener series (Table 1). Examination of 9 in the in vitro assay revealed that this was the case, as this substructure provided $13 \%$ enzyme inhibition at a $50 \mu \mathrm{M}$ concentration (Table 2). These data both underscore the importance of an ionizable, aliphatic amine to the potency of this class of inhibitors, as well as the need for the ACQ component.

To further probe the requirements of pharmacophore component E, a new derivative of SMNPI 3 (Scheme 1) possessing a non-ionizable oxygen atom at the $3 \alpha$ position of the cholateacetate was generated. Designated 10 (Scheme 1), this molecule was designed to determine if an ether oxygen might also suffice at this key position. For example, it was hypothesized that a water molecule might bridge a hydrogen bond between the Glu 63 side chain carboxylate and the ether oxygen of 10. Interestingly, examination of $\mathbf{1 0}$ at $50 \mu \mathrm{M}$ concentration resulted in only $9 \%$ enzyme inhibition (Table 2), providing additional evidence that the ionizable, aliphatic amine found in SMNPIs 1-4 is interacting with an unprotonated acidic residue, as predicted by our molecular models (Figures 3 and 4).

Finally, to determine if it would be possible to restore the inhibitory potency of $\mathbf{1 0}$, the $3 \alpha$-O-cholate-acetate and ACQ components were tethered with an extended linker incorporating a central, secondary amine. Gratifying, the resulting derivative, 11 (Scheme 1), was found to inhibit the BoNT/A LC by $62 \%$ at a $50 \mu \mathrm{M}$ concentration (Table 2). In a docked model of $\mathbf{1 1}$ (Figure 5), the secondary amine in the extended linker engages in a hydrogen bond with the side chain carboxylate of Glu 63, 


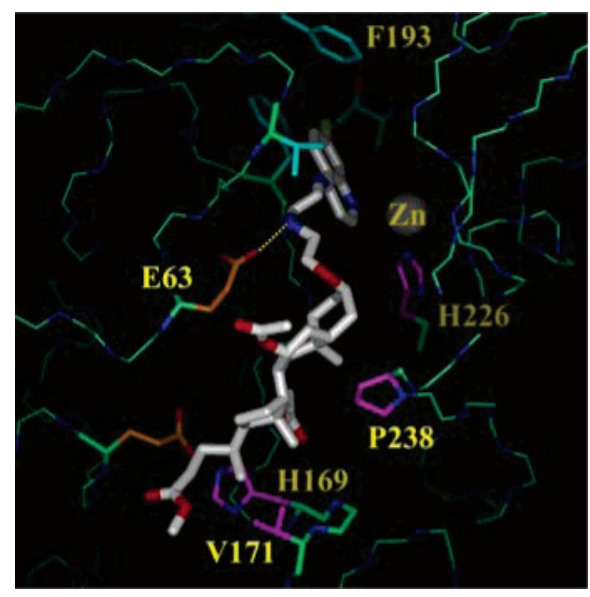

Figure 5. SMNPI 11 docked in the BoNT/A LC substrate binding cleft. All colors, stick thicknesses, and the dashed line are as indicated in Figure 3. As compared to SMNPIs 1-3, the cholate-acetate portion of the inhibitor adopts a shallower binding mode as a result of increasing the length of the flexible tether between the ACQ and cholate-acetate components.

in a manner similar to that of the secondary amine found in the linker of SMNPI 1 (Figure 3A). Furthermore, the extended tether also orients the $3 \alpha$-oxygen atom of $\mathbf{1 1}$ toward the stern layer, eliminating the possibility of unfavorable contacts with polar enzyme residues (Figure 5). However, due to the increased length of the SMNPI, the cholate-acetate portion of $\mathbf{1 1}$ cannot attain the same depth of binding as that of $\mathbf{1 - 3}$, thus rationalizing its reduced activity (for comparison, 3 inhibits the BoNT/A LC by $90 \%$ at $50 \mu \mathrm{M}$ concentration). Specifically, the extended linker forces the cholate-acetate portion of $\mathbf{1 1}$ to adopt a shallower binding mode, with its C23 methoxycarbonyl oriented outside of the substrate binding cleft (Figure 5). In addition, while the SMNPI's $12 \alpha$-acetyl group faces binding subsite 2, it does so in a sterically shallow location in the substrate cleft that is adjacent to flexible loop 2 (Figure 5). For comparison, the $12 \alpha$-acetyl substituent of $\mathbf{3}$ binds in a deeper location in subsite 2 that is directly behind catalytic engine residue His 226 (Figure 3C). However, it is noteworthy that the C10 methyl of $\mathbf{1 1}$ does adopt a binding site location that occupies the steric space behind Pro 238, as also observed for substituents comprising pharmacophore component G in SMNPIs 1-3.

Based on the examination of substructures 5-9 and derivatives $\mathbf{1 0}$ and 11, the importance of pharmacophore component E to the potencies of SMNPIs in this structural class is evident. Indeed, Table 2 shows that each time this pharmacophoric feature is added, the potency of its derivative increases substantially, in one of the most extreme cases, compound $\mathbf{1 0}$ versus SMNPI 11, by nearly 7 -fold. Additionally, replacement of the aliphatic amine in SMNPI 3 with a polar, non-ionizable oxygen isostere results in an inhibitor that is 10-fold less active. Interestingly, even as pharmacophore component $\mathrm{E}$ is key to BoNT/A LC inhibition, it is also central to the hypothesis that these molecules may act as BoNT translocation inhibitors, as the ionizable, aliphatic amine would be responsible for elevating the $\mathrm{pH}$ of the toxin-induced endosome. Indeed, we hypothesize that alkalinization of the endosome by the ionizable amine component of the ACQs will potentially result in the trapping and accumulation of these small molecules in the acidic compartment; hence, the in vivo efficacies of the ACQ-based inhibitors may be even more pronounced than anticipated from in vitro studies.

Chemistry. The syntheses of SMNPIs $\mathbf{1 - 4}$, and derivatives 10 and 11, have not been reported. Because of the process whereby 1-4 were identified as BoNT/A LC inhibitors, presenting their syntheses at the beginning of the Results and Discussion would not follow the scientific evolution of this study. Therefore, descriptions of the syntheses of the inhibitors and derivatives are provided at a non-traditional, but more logical, location in the text.

Targets 1, 2, 3, and $\mathbf{1 1}$ were obtained by amination reactions of corresponding precursors with 6 (Scheme 1). The key aldehyde 15 was obtained from alcohol 13, which was allylated and subsequently ozonized (Scheme 1). Amino ether 11 (43\% from 14) was obtained in a reductive amination reaction between 6 and aldehyde 15 (Scheme 1). Alternatively, ketone 19 (obtained from 13) ${ }^{43}$ underwent amination with $\mathbf{6}$ to afford quinoline epimers 2 and 3 (Scheme 1) in a ratio of 1.3:1. Interestingly, although the reactive intermediate is an imine (iminium cation, $\mathrm{sp}^{2} \mathrm{C} 3$ ), the reductive amination of the cholic acid derivative ( $5 \beta$-series) afforded epimeric $\mathbf{2}$ and $\mathbf{3}$ in comparable amounts, unlike the reductions of $5 \beta$-3-ketones affording almost exclusively equatorial $3 \alpha$-epimer. ${ }^{44}$ Azide 17, obtained from alcohol 16, was transformed into amine 18 and coupled to 4,7-dichloroquinoline, affording compound $\mathbf{1 0}$ (Scheme 1). Finally, quinolines 6 and $7^{45}$ and trisquinoline 4 $(33 \%)$ were obtained according to a well-established procedure ${ }^{43}$ using the corresponding di- and triamines and 4,7-dichloroquinoline.

\section{Conclusion}

An expanded/refined pharmacophore for BoNT/A LC inhibition $^{33}$ was used to identify four new, potent SMNPIs of the ACQ structural class. In each case, docking of the inhibitors demonstrated that they follow a consistent structure-based theme, engaging in intermolecular substrate binding cleft contacts modeled for other SMNPIs. ${ }^{31-33}$ However, unlike any other BoNT/A LC inhibitors that we have identified to date, ${ }^{31,33}$ SMNPIs $\mathbf{1 - 4}$ and $\mathbf{1 1}$ incorporate a new pharmacophore component $\mathrm{G}$, which is predicted to serve as a hydrophobic anchor at the edge of the substrate binding cleft, resulting in greater cleft complementarity and occupancy. This provides additional support that molecular scaffolds, which are larger than many reported BoNT/A LC inhibitors, ${ }^{31,40-42}$ are needed to provide superior inhibition. Finally, examination of substructures composing 1-4 (i.e., compounds 5-9), as well as derivatives $\mathbf{1 0}$ and 11, revealed the critical importance of positive-ionizable pharmacophore component $\mathrm{E}$ to the potencies of inhibitors in the structural class. This information will be central to the structure-based design of future ACQ-based inhibitors of the BoNT/A LC.

\section{Experimental Section}

Chemistry. General Considerations. Melting points were determined on a Boetius PMHK or a Mel-Temp apparatus and were not corrected. Optical rotations were measured on a Rudolph Research Analytical automatic polarimeter, Autopol IV. IR spectra were recorded on a Perkin-Elmer spectrophotometer FT-IR 1725X. NMR spectra were recorded on Varian Gemini-200, Varian XL300, and Bruker AM-250 spectrometers in the indicated solvent using TMS as internal standard. EI and CI mass spectra were recorded on a MS Finnigan-MAT 8230 spectrometer with double focusing reverse geometry, using isobutane (CI). Microanalyses were performed by M-H-W Laboratories, Phoenix, AZ. Thin-layer chromatography (TLC) was performed on precoated Merck silica gel $60 \mathrm{~F}_{254}$ and RP-18 $\mathrm{F}_{254}$ plates. For column chromatography, Lobar LichroPrep Si $60(40-63 \mu \mathrm{m})$ and RP-18 $(40-63 \mu \mathrm{m})$ columns coupled to a Waters RI 401 detector were used.

4-Amino-7-chloroquinoline (5), $N^{1}$-(7-chloroquinolin-4-yl)ethane-1,2-diamine (6), $N^{1}$-(7-chloroquinolin-4-yl)-propane-1,3- 
diamine (7), and methyl $3 \alpha$-amino-7 $\alpha, 12 \alpha$-diacetoxycholan-24-oate (9) were prepared according to known procedures. ${ }^{45-49}$ Methyl cholate triacetate $(\mathbf{8})$ was purchased form Aldrich and used as obtained.

$N$-(3 $\alpha, 7 \alpha, 12 \alpha$-Triacetoxy-5 $\beta$-cholan-24-yl)- $N^{\prime}$-(7'-chloroquinolin-4'-yl)-ethane-1,2-diamine (1). Methanesulfonyl chloride (84.9 $\mu \mathrm{L}, 1.09 \mathrm{mmol})$ was added to an ice-cold solution of $3 \alpha, 7 \alpha, 12 \alpha-$ diacetoxy-5 $\beta$-cholan-24-ol ${ }^{50}$ (12) (Scheme 1) (381.9 mg, 0.73 mmol $)$ in dry pyridine $(10 \mathrm{~mL})$, and the resulting mixture was stirred at $0{ }^{\circ} \mathrm{C}$ for $1 \mathrm{~h}$. Diethyl-ether $(30 \mathrm{~mL})$ was added, and the organic layer was washed with diluted $\mathrm{HCl}(1 / 1)$, followed by sat. $\mathrm{NaHCO}_{3}$ $(2 \times 15 \mathrm{~mL})$ and brine, and dried over anhydrous $\mathrm{Na}_{2} \mathrm{SO}_{4}$. The solvent was removed under reduced pressure, leaving the crude mesylate $(411.7 \mathrm{mg} ; 94 \%)$. In the next step, the crude mesylate and $6(305.9 \mathrm{mg}, 1.38 \mathrm{mmol})$ were stirred overnight at $60{ }^{\circ} \mathrm{C}$ in dry DMF ( $4 \mathrm{~mL})$ and evaporated to dryness. The resulting solid was purified on $\mathrm{S} \mathrm{SiO}_{2}$ column (dry-flesh, AcOEt $(8 \times 10 \mathrm{~mL})$, AcOEt $\left./ \mathrm{MeOH} / \mathrm{NH}_{3}=9 / 1 / 1(14 \times 10 \mathrm{~mL})\right)$. Fractions were combined, evaporated to dryness, suspended in $\mathrm{CH}_{2} \mathrm{Cl}_{2}$, and undissolved $\mathbf{6}$ was removed by filtration. The dichloromethane extract was evaporated to dryness and purified by column chromatography (Lobar Lichroprep B, eluent $\mathrm{MeOH} / \mathrm{H}_{2} \mathrm{O}=98 / 2$, Lobar B Lichroprep RP, eluent $\mathrm{MeOH} / \mathrm{H}_{2} \mathrm{O}=9 / 1$, and Lobar A Lichroprep RP-18, eluent $\left.\mathrm{MeOH} / \mathrm{H}_{2} \mathrm{O}=85 / 15\right)$ to afford 1 (104 $\mathrm{mg}(24 \%))$. Colorless foam softness at $95-98^{\circ} \mathrm{C}$. $[\alpha]^{20} \mathrm{D}=+30.0$ $\left(c=1.0, \mathrm{CH}_{2} \mathrm{Cl}_{2}\right)$. IR (KBr): $3405 \mathrm{~m}, 2943 \mathrm{~s}, 2875 \mathrm{~m}, 1736 \mathrm{~s}, 1618 \mathrm{w}$, $1584 \mathrm{~s}, 1540 \mathrm{w}, 1452 \mathrm{~m}, 1378 \mathrm{~s}, 1334 \mathrm{w}, 1250 \mathrm{~s}, 1143 \mathrm{w}, 1068 \mathrm{w}$, 1030m, 970w, 941w, 887w, 853w, 814w, 774w, 735w, 647w, $617 \mathrm{w}, 588 \mathrm{w} \mathrm{cm}^{-1} .{ }^{1} \mathrm{H}$ NMR $\left(200 \mathrm{MHz}, \mathrm{CDCl}_{3}\right): \delta 8.49(\mathrm{~d}, J=$ $\left.5.3, \mathrm{H}-\mathrm{C}\left(2^{\prime}\right)\right), 7.93\left(\mathrm{~d}, J=2.0, \mathrm{H}-\mathrm{C}\left(8^{\prime}\right)\right), 7.75(\mathrm{~d}, J=9.0$, $\left.\mathrm{H}-\mathrm{C}\left(5^{\prime}\right)\right), 7.4-7.3\left(\mathrm{~m}, \mathrm{H}-\mathrm{C}\left(6^{\prime}\right)\right), 6.36\left(\mathrm{~d}, J=5.3, \mathrm{H}-\mathrm{C}\left(3^{\prime}\right)\right), 6.05$ (bs, $\mathrm{H}-\mathrm{N}$ ), 5.09 (bs, H-C(12)), 4.95-4.85 (m, H-C(7)), 4.60$4.50(\mathrm{~m}, \mathrm{H}-\mathrm{C}(3)), 3.40-3.30\left(\mathrm{~m}, 2 \mathrm{H}-\mathrm{C}\left(9^{\prime}\right)\right), 3.10-2.95(\mathrm{~m}, 2 \mathrm{H}-$ $\left.\mathrm{C}\left(10^{\prime}\right)\right), 2.70-2.50(\mathrm{~m}, \mathrm{H}-\mathrm{N}), 2.40-2.20(\mathrm{~m}, 2 \mathrm{H}-\mathrm{C}(24)), 2.12$ (s, $\mathrm{CH}_{3} \mathrm{COO}-$ ), 2.08 (s, $\mathrm{CH}_{3} \mathrm{COO}-$ ), 2.05 (s, $\mathrm{CH}_{3} \mathrm{COO}-$ ), 0.91 (s, $\left.\mathrm{H}_{3} \mathrm{C}-\mathrm{C}(10)\right), 0.82\left(\left(\mathrm{~d}, J=6.2, \mathrm{H}_{3} \mathrm{C}-\mathrm{C}(20)\right), 0.71\left(\mathrm{~s}, \mathrm{H}_{3} \mathrm{C}-\right.\right.$ $\mathrm{C}(13)) .{ }^{13} \mathrm{C}$ NMR $\left(50 \mathrm{~Hz}, \mathrm{CDCl}_{3}\right): \delta 170.53,170.37,151.87$, 149.92, 148.88, 134.70, 128.34, 125.07, 121.44, 117.28, 98.99, 75.32, 73.98, 70.61, 49.67, 47.54, 47.40, 44.90, 43.26, 41.92, 40.77, $37.58,34.83,34.52,34.18,33.18,31.10,28.77,27.18,26.73,26.53$, $25.44,22.65,22.42,21.50,21.38,21.30,17.77,12.09$. MS-CI $(\mathrm{m} / \mathrm{z}$ (\%)): $725\left[(\mathrm{M}+\mathrm{H})^{+},(100)\right], 667$ (10), 223 (100), 193 (25).

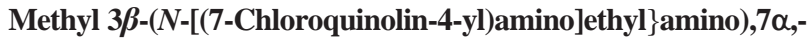
$12 \alpha$-diacetoxy-5 $\beta$-cholan-24-oate (2) and Methyl $3 \alpha-(N-[(7-$ Chloroquinolin-4-yl)amino] ethyl $\}$ amino), $7 \alpha, 12 \alpha$-diacetoxy-5 $\beta$ cholan-24-oate (3). Methyl $7 \alpha, 12 \alpha$-diacetoxy-3-oxo-5 $\beta$-cholan-24oate $^{51}$ (19) (Scheme 1) (504 mg, $\left.1.0 \mathrm{mmol}\right)$ and 6 (1.7 g, $\left.7.7 \mathrm{mmol}\right)$ was dissolved in a $\mathrm{CH}_{3} \mathrm{CN} / \mathrm{MeOH}(2 / 1,15 \mathrm{~mL})$ mixture, and $\mathrm{NaBH}_{3} \mathrm{CN}$ (77.3 mg, $1.23 \mathrm{mmol}$ ) was added in one portion. The resulting mixture was stirred for $2 \mathrm{~h}$ at room temperature, followed by the addition of glacial $\mathrm{AcOH}$ ( 5 drops). The stirring was continued until TLC indicated the consumption of all starting ketone, ca. $1 \mathrm{~h}$. The solvent was removed under reduced pressure, and the obtained solid was triturated with $\mathrm{CH}_{2} \mathrm{Cl}_{2}(3 \times 40 \mathrm{~mL})$. The dichloromethane extracts were combined, the solvent was removed, and the products were separated by column chromatography (Lobar B Lichroprep RP-18, eluent $\mathrm{MeOH} / \mathrm{H}_{2} \mathrm{O}=9 / 1$ ) to afford $\mathbf{2}$ and $\mathbf{3}$.

2: Yield $240.8 \mathrm{mg}(34 \%)$. Colorless foam softens at 212-215 ${ }^{\circ} \mathrm{C} .[\alpha]^{20}{ }_{\mathrm{D}}=+35.0\left(c=1.0 \mathrm{~g}, \mathrm{CH}_{2} \mathrm{Cl}_{2}\right)$. IR $(\mathrm{KBr}): 3331 \mathrm{~m}, 3243 \mathrm{~m}$, $2938 \mathrm{~s}, 2875 \mathrm{~m}, 1731 \mathrm{~s}, 1618 \mathrm{~m}, 1594 \mathrm{~s}, 1530 \mathrm{~m}, 1471 \mathrm{~m}, 1451 \mathrm{~m}$, $1378 \mathrm{~s}, 1333 \mathrm{~m}, 1250 \mathrm{~s}, 1172 \mathrm{~m}, 1142 \mathrm{w}, 1108 \mathrm{w}, 1029 \mathrm{~m}, 961 \mathrm{w}, 931 \mathrm{w}$, $887 \mathrm{w}, 853 \mathrm{w}, 809 \mathrm{~m}, 765 \mathrm{w}, 730 \mathrm{w}, 608 \mathrm{w}, 509 \mathrm{w} \mathrm{cm}{ }^{-1} .{ }^{1} \mathrm{H}$ NMR $(200$ $\left.\mathrm{MHz}, \mathrm{CDCl}_{3}\right): \delta 8.52\left(\mathrm{~d}, J=5.6, \mathrm{H}-\mathrm{C}\left(2^{\prime}\right)\right), 7.95(\mathrm{~d}, J=2.0$, $\left.\mathrm{H}-\mathrm{C}\left(8^{\prime}\right)\right), 7.67\left(\mathrm{~d}, J=9.0, \mathrm{H}-\mathrm{C}\left(5^{\prime}\right)\right), 7.4-7.3\left(\mathrm{~m}, \mathrm{H}-\mathrm{C}\left(6^{\prime}\right)\right), 6.38$ $\left(\mathrm{d}, J=5.2, \mathrm{H}-\mathrm{C}\left(3^{\prime}\right)\right), 6.0\left(\mathrm{bs}, \mathrm{H}-\mathrm{N}\right.$, exchangeable with $\left.\mathrm{D}_{2} \mathrm{O}\right)$, 5.10 (bs, $\mathrm{H}-\mathrm{C}(12))$, 4.95-4.85 (m, $\mathrm{H}-\mathrm{C}(7)), 3.66\left(\mathrm{~s}, \mathrm{CH}_{3} \mathrm{O}_{2} \mathrm{C}\right)$, 3.40-3.20 (m, H-C $\left.\left(9^{\prime}\right)\right), 3.00-2.90$ (m, H-C $\left.\left(10^{\prime}\right), \mathrm{H} \alpha-\mathrm{C}(3)\right), 2.12$ (s, $\left.\mathrm{CH}_{3} \mathrm{COO}-\right), 2.08$ (s, $\left.\mathrm{CH}_{3} \mathrm{COO}-\right), 0.96\left(\mathrm{~s}, \mathrm{H}_{3} \mathrm{C}-\mathrm{C}(10)\right), 0.82$ $\left(\mathrm{d}, J=6.0, \mathrm{H}_{3} \mathrm{C}-\mathrm{C}(20)\right), 0.74\left(\mathrm{~s}, \mathrm{H}_{3} \mathrm{C}-\mathrm{C}(13)\right) .{ }^{13} \mathrm{C} \mathrm{NMR}(50 \mathrm{~Hz}$, $\left.\mathrm{CDCl}_{3}\right): \delta 174.57,170.49,170.42,152.14,149.85,149.12,134.75$,
$128.78,125.20,121.04,117.35,99.23,95.75,75.47,71.01,52.04$, 51.49, 47.30, 44.99, 44.81, 43.32, 42.33, 37.67, 36.16, 34.90, 34.56, $33.54,31.12,30.83,30.70,30.02,28.28,27.13,25.64,24.93,23.25$, $22.74,21.58,21.30,17.44,12.15 . \mathrm{MS}-\mathrm{CI}(\mathrm{m} / \mathrm{z}(\%)): 712[(\mathrm{M}+$ $\left.2)^{+},(100)\right], 224(80), 193(40)$.

3: Yield $181.5 \mathrm{mg}(26 \%)$. Colorless foam softens at $91-95^{\circ} \mathrm{C}$. $[\alpha]^{20}{ }_{\mathrm{D}}=+49.0\left(c=1.0, \mathrm{CH}_{2} \mathrm{Cl}_{2}\right)$. IR $(\mathrm{KBr}): 3410 \mathrm{~m}, 2943 \mathrm{~m}$, $2870 \mathrm{~m}, 1736 \mathrm{~s}, 1618 \mathrm{w}, 1589 \mathrm{~s}, 1540 \mathrm{w}, 1452 \mathrm{~m}, 1378 \mathrm{~m}, 1334 \mathrm{w}$, 1250s, 1200w, 1172w, 1142w, 1084w, 1030m, 971w, 941w, 888w, $853 \mathrm{w}, 814 \mathrm{w}, 770 \mathrm{w}, 647 \mathrm{w}, 613 \mathrm{w}, 559 \mathrm{w}, 509 \mathrm{w}, 480 \mathrm{w}, 455 \mathrm{w} \mathrm{cm}{ }^{-1}$. ${ }^{1} \mathrm{H}$ NMR $\left(200 \mathrm{MHz}, \mathrm{CDCl}_{3}\right): \delta 8.46\left(\mathrm{~d}, J=5.4, \mathrm{H}-\mathrm{C}\left(2^{\prime}\right)\right), 7.90$ $\left(\mathrm{d}, J=2.0, \mathrm{H}-\mathrm{C}\left(8^{\prime}\right)\right), 7.71\left(\mathrm{~d}, J=9.0, \mathrm{H}-\mathrm{C}\left(5^{\prime}\right)\right), 7.32(\mathrm{dd}, J=$ $\left.2.2, J=9.0, \mathrm{H}-\mathrm{C}\left(6^{\prime}\right)\right), 6.34\left(\mathrm{~d}, J=5.6, \mathrm{H}-\mathrm{C}\left(3^{\prime}\right)\right), 6.12(\mathrm{bs}, \mathrm{H}-\mathrm{N}$, exchangeable with $\left.\mathrm{D}_{2} \mathrm{O}\right), 5.08$ (bs, $\left.\mathrm{H}-\mathrm{C}(12)\right), 4.95-4.85(\mathrm{~m}$, $\mathrm{H}-\mathrm{C}(7)), 3.66$ (, $\left.\mathrm{CH}_{3} \mathrm{O}_{2} \mathrm{C}\right), 3.45-3.35$ (m, $\left.\mathrm{H}-\mathrm{C}\left(9^{\prime}\right)\right), 3.10-3.00$ (m, $\left.\mathrm{H}-\mathrm{C}\left(10^{\prime}\right)\right), 2.92$ (bs, $\mathrm{H}-\mathrm{N}$, exchangeable with $\left.\mathrm{D}_{2} \mathrm{O}\right), 2.43(\mathrm{~m}$, $\mathrm{H} \beta-\mathrm{C}(3)), 2.08$ (s, $\mathrm{CH}_{3} \mathrm{COO}-$ ), 2.03 (s, $\mathrm{CH}_{3} \mathrm{COO}-$ ), 0.92 (s, $\left.\mathrm{H}_{3} \mathrm{C}-\mathrm{C}(10)\right), 0.81\left(\mathrm{~d}, J=6.0, \mathrm{H}_{3} \mathrm{C}-\mathrm{C}(20)\right), 0.73$ (s, $\left.\mathrm{H}_{3} \mathrm{C}-\mathrm{C}(13)\right)$. ${ }^{13} \mathrm{C}$ NMR $\left(50 \mathrm{~Hz}, \mathrm{CDCl}_{3}\right): \delta 174.57,170.66,170.51,151.74$, $149.92,148.77,134.94,128.37,125.27,121.41,117.26,99.01$, $75.43,70.83,57.97,51.51,47.27,44.99,44.48,43.32,42.35,41.48$ $37.67,36.42$, 35.30, 34.72, 34.52, 31.37, 30.79, 30.66, 28.90, 28.02, $27.09,25.47,22.74,21.60,21.36,17.41,12.13$. MS-EI $(\mathrm{m} / \mathrm{z}(\%))$ : $\left.711[\mathrm{M}+\mathrm{H})^{+},(30)\right], 668(25), 459(30), 192$ (100).

Tris[3-(7-chloroquinolin-4-yl)aminopropyl]amine (4). Following the procedure of Vennerstrom et al., 43 a solution of 4,7dichloroquinoline $(2.97 \mathrm{~g}, 15 \mathrm{mmol})$, triethylamine (1.52 g, 15 $\mathrm{mmol})$, and tris-(3-aminopropyl)amine $(0.94 \mathrm{~g}, 5 \mathrm{mmol})$ in $\mathrm{N}$ methylpyrrolidinone (NMP, $10 \mathrm{~mL}$ ) was subject to 10 purge-cycles using a Firestone valve and then heated to reflux for $7 \mathrm{~h}$ under a slight positive $\mathrm{N}_{2}$ pressure. After the reaction mixture cooled to room temperature, ether $(50 \mathrm{~mL})$ and water $(50 \mathrm{~mL})$ were added with stirring. After the mixture was cooled in the refrigerator, a tan solid was filtered and washed with water and ethyl acetate to provide, after crystallization from methanol, 4 (1.12 g, 33\%). mp $198-200{ }^{\circ} \mathrm{C} ;{ }^{1} \mathrm{H}$ NMR $\left(300 \mathrm{MHz}, \mathrm{DMSO}-d_{6}\right): \delta 1.71-2.01(\mathrm{~m}$, $6 \mathrm{H}), 2.42-2.75(\mathrm{~m}, 6 \mathrm{H}), 3.24(\mathrm{~d}, J=4.8 \mathrm{~Hz}, 6 \mathrm{H}), 6.33(\mathrm{~d}, J=$ $5.5 \mathrm{~Hz}, 3 \mathrm{H}), 7.28$ (br s, $3 \mathrm{H}), 7.40(\mathrm{dd}, J=8.9,1.9 \mathrm{~Hz}, 3 \mathrm{H}), 7.77$ $(\mathrm{d}, J=2.0 \mathrm{~Hz}, 3 \mathrm{H}), 8.22(\mathrm{~d}, J=9.1 \mathrm{~Hz}, 3 \mathrm{H}), 8.31(\mathrm{~d}, J=5.3 \mathrm{~Hz}$, $3 \mathrm{H}) .{ }^{13} \mathrm{C}$ NMR $\left(75 \mathrm{MHz}, \mathrm{DMSO}-d_{6}\right): \delta 25.35,34.82,40.84,51.25$, $98.50,117.40,123.94,127.47,133.29,149.01,150.01,151.79$.

Methyl $3 \alpha-(N$-[(7-Chloroquinolin-4-yl)amino]ethyl $\})$ oxy, $7 \alpha$,$12 \alpha$-diacetoxy-5 $\beta$-cholan-24-oate (10). A mixture of primary amine 18 (Scheme 1) (87 mg, $0.16 \mathrm{mmol}$ ), 4,7-dichloroquinoline (95 mg, $0.48 \mathrm{mmol}$ ), and phenol (223 mg, $2.32 \mathrm{mmol}$ ) was stirred for $24 \mathrm{~h}$ at $120^{\circ} \mathrm{C}$. Upon cooling, the mixture was dissolved in $\mathrm{CH}_{2} \mathrm{Cl}_{2}$ and washed with dilute $\mathrm{NaOH}(6 \times 20 \mathrm{~mL})$ and brine, and dried over anhydrous $\mathrm{Na}_{2} \mathrm{SO}_{4}$. The solvent was removed under reduced pressure, and the product was isolated by column $\mathrm{SiO}_{2}$ chromatography: dry-flash, $2 \times 7 \mathrm{~mL}$ hexane, $2 \times 7 \mathrm{~mL}$ EtOAc: hexane (9:1), $2 \times 7 \mathrm{~mL}$ EtOAc, $10 \times 7 \mathrm{~mL}$ EtOAc:MeOH (9:1). Yield $86.4 \mathrm{mg}(77 \%)$. Colorless foam softness at $86-89^{\circ} \mathrm{C}$. $[\alpha]^{20} \mathrm{D}$ $=+39.13\left(c=1.61, \mathrm{CH}_{2} \mathrm{Cl}_{2}\right)$. IR (film): $3531 \mathrm{w}, 3413 \mathrm{w}, 2951 \mathrm{~s}$, $2870 \mathrm{~m}, 1733 \mathrm{~s}, 1611 \mathrm{w}, 1581 \mathrm{~s}, 1536 \mathrm{w}, 1446 \mathrm{~m}, 1376 \mathrm{~s}, 1333 \mathrm{w}, 1248 \mathrm{~s}$, $1200 \mathrm{w}, 1172 \mathrm{w}, 1146 \mathrm{w}, 1101 \mathrm{~m}, 1024 \mathrm{~m}, 967 \mathrm{w}, 940 \mathrm{w}, 850 \mathrm{w}, 810 \mathrm{w}$, $768 \mathrm{w}, \mathrm{cm}^{-1} .{ }^{1} \mathrm{H}$ NMR $\left(200 \mathrm{MHz}, \mathrm{CDCl}_{3}\right): 8.54$ (d, $J=5.4$, $\left.\mathrm{H}-\mathrm{C}\left(2^{\prime}\right)\right), 7.97\left(\mathrm{~d}, J=2.2, \mathrm{H}-\mathrm{C}\left(8^{\prime}\right)\right), 7.66\left(\mathrm{~d}, J=9.2, \mathrm{H}-\mathrm{C}\left(5^{\prime}\right)\right)$, $7.38\left(\mathrm{dd}, J=2.2, J=8.9, \mathrm{H}-\mathrm{C}\left(6^{\prime}\right)\right), 6.43\left(\mathrm{~d}, J=5.4, \mathrm{H}-\mathrm{C}\left(3^{\prime}\right)\right)$, 5.46 (bs, $\mathrm{H}-\mathrm{N}$ ), 5.08 (bs, $\mathrm{H}-\mathrm{C}(12)), 4.95-4.85$ (m, H-C(7)), 3.8$3.9\left(\mathrm{~m}, \mathrm{ArNH}-\mathrm{CH}_{2}-\mathrm{CH}_{2} \mathrm{O}-\right), 3.66\left(\mathrm{~s}, \mathrm{CH}_{3} \mathrm{O}_{2} \mathrm{C}\right), 3.55-3.40(\mathrm{~m}$, $\left.\mathrm{ArNH}-\mathrm{CH}_{2}-\mathrm{CH}_{2}-\mathrm{O}-\right)$, 3.30-3.12 (m, $\left.\mathrm{H} \beta-\mathrm{C}(3)\right), 2.10$ (s, $\mathrm{CH}_{3-}$ $\mathrm{COO}-$ ), 2.04 (s, $\mathrm{CH}_{3} \mathrm{COO}-$ ), 0.92 ( $\left.\mathrm{s}, \mathrm{H}_{3} \mathrm{C}-\mathrm{C}(10)\right), 0.80$ (d, $J=$ 5.8, $\left.\mathrm{H}_{3} \mathrm{C}-\mathrm{C}(20)\right), 0.73$ (s, $\left.\mathrm{H}_{3} \mathrm{C}-\mathrm{C}(13)\right) .{ }^{13} \mathrm{C}$ NMR $(50 \mathrm{~Hz}$, $\left.\mathrm{CDCl}_{3}\right): 174.54,170.64,170.51,151.92,149.74,148.99,134.95$, $128.78,125.43,120.79,117.26,99.29,79.77,75.4,70.77,65.66$, $51.47,47.29,45.01,43.32,42.9,41.08,37.69,35.58,34.76,34.58$, $31.34,30.79,30.68,28.9,27.46,27.09,25.51,22.72,22.56,21.58$, 21.41, 17.41, 12.15. MS-CI $\left.(\mathrm{m} / \mathrm{z}(\%)): 712[\mathrm{M}+\mathrm{H})^{+},(100)\right], 688$ (5), 651 (10), 591 (5), 477 (2), 370 (3), 317 (2), 279 (2), 192 (3).

$N$-(Methyl $7 \alpha, 12 \alpha$-diacetoxy-5 $\beta$-cholan-24-oate,3 $\alpha$-yloxy)ethyl- $N^{\prime}$-(7-chloroquinolin-4-yl)-ethane-1,2-diamine (11). A sus- 
pension of crude 15 (Scheme 1) (203 mg, $0.37 \mathrm{mmol}$ ) and 6 (189 $\mathrm{mg}, 0.85 \mathrm{mmol}$ ) was stirred for $30 \mathrm{~min}$ at room temperature, and $\mathrm{NaBH}(\mathrm{OAc})_{3}(180.4 \mathrm{mg}, 0.85 \mathrm{mmol})$ was then added in a single portion. Stirring was continued overnight, solvent was removed, and the product was isolated by column chromatography on $\mathrm{SiO}_{2}$ : dry-flash, eluent EtOAc/MeOH/ $\mathrm{NH}_{3}$ conc. (36:1:1). Yield $120 \mathrm{mg}$ (43\% from 14 (Scheme 1)), colorless solid. $\left[\alpha{ }^{20}{ }_{\mathrm{D}}=+38.56(c=\right.$ $1.53, \mathrm{CH}_{2} \mathrm{Cl}_{2}$ ). IR (KBr): 3310w, 3057w, 2941m, 2868m, 1733s, $1674 \mathrm{w}, 1612 \mathrm{w}, 1581 \mathrm{~s}, 1539 \mathrm{w}, 1450 \mathrm{~m}, 1375 \mathrm{~m}, 1333 \mathrm{w}, 1248 \mathrm{~s}$, $1147 \mathrm{w}, 1081 \mathrm{w}, 1024 \mathrm{~m}, 967 \mathrm{w}, 880 \mathrm{w}, 851 \mathrm{w}, 812 \mathrm{w}, 769 \mathrm{w} \mathrm{cm}{ }^{-1}$. ${ }^{1} \mathrm{H}$ NMR $\left(200 \mathrm{MHz}, \mathrm{CDCl}_{3}\right): 8.50\left(\mathrm{~d}, J=5.4, \mathrm{H}-\mathrm{C}\left(2^{\prime}\right)\right), 7.94(\mathrm{~d}$, $\left.J=2.2, \mathrm{H}-\mathrm{C}\left(8^{\prime}\right)\right), 7.76\left(\mathrm{~d}, J=9.2, \mathrm{H}-\mathrm{C}\left(5^{\prime}\right)\right), 7.37(\mathrm{dd}, J=2.2$, $\left.J=8.8, \mathrm{H}-\mathrm{C}\left(6^{\prime}\right)\right), 6.38\left(\mathrm{~d}, J=5.4, \mathrm{H}-\mathrm{C}\left(3^{\prime}\right)\right), 6.02(\mathrm{bs}, \mathrm{H}-\mathrm{N})$, 5.06 (bs, $\mathrm{H}-\mathrm{C}(12))$, 4.95-4.85 (m, $\mathrm{H}-\mathrm{C}(7)), 3.70-3.5(\mathrm{~m}$, $\mathrm{CH}_{3} \mathrm{O}_{2} \mathrm{C}$ and $\left.\mathrm{ArNH}-\mathrm{CH}_{2}-\mathrm{CH}_{2} \mathrm{NH}-\right), 3.40-3.30$ (m, NH$\left.\mathrm{CH}_{2}-\mathrm{CH}_{2}-\mathrm{O}\right), 3.20-3.00\left(\mathrm{~m}, \mathrm{H}-\mathrm{C}(3)\right.$ and $\mathrm{ArNH}-\mathrm{CH}_{2}-\mathrm{CH}_{2}-$ $\mathrm{NH}-$ ), 2.90-2.80 (m, NH- $\left.\mathrm{CH}_{2}-\mathrm{CH}_{2}-\mathrm{O}\right), 2.08$ (s, $\mathrm{CH}_{3} \mathrm{COO}-$ ), 2.04 (s, $\mathrm{CH}_{3} \mathrm{COO}-$ ), 0.90 (s, $\left.\mathrm{H}_{3} \mathrm{C}-\mathrm{C}(10)\right), 0.79$ (d, $J=6.0, \mathrm{H}_{3} \mathrm{C}-$ $\mathrm{C}(20)), 0.72$ (s, $\left.\mathrm{H}_{3} \mathrm{C}-\mathrm{C}(13)\right) .{ }^{13} \mathrm{C} \mathrm{NMR}\left(50 \mathrm{~Hz}, \mathrm{CDCl}_{3}\right)$ : 174.56 , $170.71,170.62,151.87,149.94,148.88,134.84,128.45,125.21$, $121.43,117.28,99.07,79.93,75.4,70.77,67.53,51.47,48.83$, 47.23, 44.99, 43.35, 41.92, 41.09, 37.65, 35.54, 34.8, 34.58, 34.49, $31.34,30.77,30.66,28.97,27.42,27.08,25.55,22.56,21.61,21.41$, 17.37, 12.13. MS-EI $\left.(\mathrm{m} / \mathrm{z}(\%)): 755[\mathrm{M}+\mathrm{H})^{+},(20)\right], 720$ (4), 696 (5), 550 (5), 448 (5), 388 (10), 372 (5), 265 (25), 249 (20), 233 (15), 223 (75), 204 (15), 194 (10), 180 (100), 165 (5), 145 (5).

Methyl $3 \alpha$-(2-Propenyloxy),7 $\alpha, 12 \alpha$-diacetoxy-5 $\beta$-cholan-24oate (14). Methyl $3 \alpha$-hydroxy- $7 \alpha, 12 \alpha$-diacetoxy- $5 \beta$-cholan-24oate $^{51,52}(\mathbf{1 3})(1 \mathrm{~g}, 2 \mathrm{mmol})$ and allyl bromide $\left.(25 \mathrm{~mL} ; 296 \mathrm{mmol})\right)$ were dissolved in $N$-methyl pyrrolidin-2-one (NMP; $6 \mathrm{~mL}$ ), and diisopropylethylamine (DIEA; $1.4 \mathrm{~mL}, 8 \mathrm{mmol}$ ) was added. The mixture was stirred for $24 \mathrm{~h}$ at $80^{\circ} \mathrm{C}$, and excess of allyl bromide was removed in vacuo. Crude product was purified by column chromatography on $\mathrm{SiO}_{2}$ : dry-flash and Lobar B LichroPrep, eluent heptane/EtOAc (8/2). Yield $845 \mathrm{mg}(78 \%)$ as colorless solid. $[\alpha]^{20}{ }_{\mathrm{D}}$ $=+52.07\left(c=1.21, \mathrm{CH}_{2} \mathrm{Cl}_{2}\right)$. IR (film): 2947s, 2870s, 1736s, $1441 \mathrm{~m}, 1377 \mathrm{~s}, 1246 \mathrm{~s}, 1198 \mathrm{~m}, 1170 \mathrm{~m}, 1125 \mathrm{~m}, 1084 \mathrm{~s}, 1024 \mathrm{~s}, 964 \mathrm{w}$, 935w, 858w, 736w cm ${ }^{-1} .{ }^{1} \mathrm{H}$ NMR $\left(200 \mathrm{MHz}, \mathrm{CDCl}_{3}\right)$ : $6.05-$ 5.80 (m, vinyllic $\mathrm{H}$ ), 5.27 (bd, $J=17.2$, vinyllic $\mathrm{H}$ ), 5.17 (bd, $J=$ $10.2 \mathrm{~Hz}$ ), 5.07 (bs, $\mathrm{H}-\mathrm{C}(12)$ ), 4.95-4.85 (m, H-C(7)), 4.01 (bdd, $\left.J=1.3, J=5.7, \mathrm{CH}_{2} \mathrm{O}-\right), 3.66\left(\mathrm{~s}, \mathrm{CH}_{3} \mathrm{O}_{2} \mathrm{C}\right), 3.25-3.05(\mathrm{~m}$, $\mathrm{H}-\mathrm{C}(3)), 2.13$ (s, $\mathrm{CH}_{3} \mathrm{COO}-$ ), 2.08 (s, $\mathrm{CH}_{3} \mathrm{COO}-$ ), 0.90 (s, $\mathrm{H}_{3} \mathrm{C}-$ $\mathrm{C}(10)), 0.80\left(\mathrm{~d}, J=6.4, \mathrm{H}_{3} \mathrm{C}-\mathrm{C}(20)\right), 0.72\left(\mathrm{~s}, \mathrm{H}_{3} \mathrm{C}-\mathrm{C}(13)\right) .{ }^{13} \mathrm{C}$ NMR $\left(50 \mathrm{~Hz}, \mathrm{CDCl}_{3}\right)$ : 174.56, 170.75, 170.79, 135.37, 116.73, 78.86, 75.38, 70.77, 69.24, 51.47, 47.29, 45.03, 43.37, 41.17, 37.73, $35.6,34.90,34.63,34.54,31.41,30.83,30.72$, 28.95, 27.31, 27.11, 25.56, 22.74, 22.58, 21.67, 21.52, 17.43, 12.16. MS-CI ( $\mathrm{m} / \mathrm{z}(\%))$ : $\left.547[\mathrm{M}+\mathrm{H})^{+},(20)\right], 487$ (80), 427 (100), 369 (50), 312 (5), 284 (3), 253 (5), 226 (4), 146 (3), 119 (2).

(Methyl $7 \alpha, 12 \alpha$-diacetoxy-5/ $\beta$-cholan-24-oate,3 $\alpha$-yloxy)acetaldehyde (15). A solution of allyl ether 14 (Scheme 1) (808.3 mg, $1.48 \mathrm{mmol}$ ) in $\mathrm{CH}_{2} \mathrm{Cl}_{2} / \mathrm{MeOH}(90 \mathrm{~mL}, 2: 1)$ was cooled to -78 ${ }^{\circ} \mathrm{C}$, and oxygen containing $2.5 \%$ ozone was bubbled through for 1 h. Excess ozone was removed with $\mathrm{Ar}, \mathrm{Me}_{2} \mathrm{~S}(5 \mathrm{~mL})$ was added, and the reaction mixture was stirred for $15 \mathrm{~min}$ at $-60{ }^{\circ} \mathrm{C}$ and for $2 \mathrm{~h}$ at room temperature. The mixture was evaporated to dryness, and the residue was dissolved in $\mathrm{CH}_{2} \mathrm{Cl}_{2}(15 \mathrm{~mL})$ and purified through a short $\mathrm{SiO}_{2}$ column using $\mathrm{CH}_{2} \mathrm{Cl}_{2}(3 \times 20 \mathrm{~mL})$. The fractions were combined and evaporated to dryness, affording crude aldehyde 7 (995 mg). This product was used in the next step without further purification.

2-(Methyl 7 $\alpha, 12 \alpha$-diacetoxy-5 $\beta$-cholan-24-oate,3 $\alpha$-yloxy)ethanol (16). This compound was quantitatively obtained in several unsuccessful reductive amination attempts (i.e., $\mathbf{1 5} \rightarrow \mathbf{1 0}$ ) using $\mathrm{NaBH}_{3} \mathrm{CN}$ or $\mathrm{NaBH}(\mathrm{OAc})_{3}$. Average yield $63 \%$ (from 14). Colorless solid. $[\alpha]^{20}{ }_{\mathrm{D}}=+64.76\left(c=1.05, \mathrm{CH}_{2} \mathrm{Cl}_{2}\right)$. IR (film): $3455 \mathrm{~m}$, $2950 \mathrm{~m}, 2870 \mathrm{~m}, 1735 \mathrm{~s}, 1651 \mathrm{w}, 1442 \mathrm{~m}, 1379 \mathrm{~s}, 1247 \mathrm{~s}, 1116 \mathrm{~m}$, $1069 \mathrm{~m}, 1069 \mathrm{~m}, 1024 \mathrm{~m}, 967 \mathrm{w}, 939 \mathrm{w}, 898 \mathrm{w}, 861 \mathrm{w}, 612 \mathrm{w} \mathrm{cm} \mathrm{cm}^{-1}$. ${ }^{1} \mathrm{H}$ NMR (200 MHz, $\left.\mathrm{CDCl}_{3}\right): 5.07$ (bs, $\left.\mathrm{H}-\mathrm{C}(12)\right), 4.92-4.86(\mathrm{~m}$, $\mathrm{H}-\mathrm{C}(7)), 3.79-3.68\left(\mathrm{~m}, \mathrm{HO}-\mathrm{CH}_{2}-\mathrm{CH}_{2}-\mathrm{O}\right), 3.66\left(\mathrm{~s}, \mathrm{CH}_{3} \mathrm{O}_{2} \mathrm{C}\right)$, 3.62-3.54 (m, $\left.\mathrm{HO}-\mathrm{CH}_{2}-\mathrm{CH}_{2}-\mathrm{O}\right), 3.24-3.06(\mathrm{~m}, \mathrm{H}-\mathrm{C}(3)), 2.14$ (s, $\mathrm{CH}_{3} \mathrm{COO}-$ ), 2.09 (s, $\mathrm{CH}_{3} \mathrm{COO}-$ ), 0.91 (s, $\left.\mathrm{H}_{3} \mathrm{C}-\mathrm{C}(10)\right), 0.80$ $\left(\mathrm{d}, J=5.8, \mathrm{H}_{3} \mathrm{C}-\mathrm{C}(20)\right), 0.72\left(\mathrm{~s}, \mathrm{H}_{3} \mathrm{C}-\mathrm{C}(13)\right) .{ }^{13} \mathrm{C}$ NMR $(50 \mathrm{~Hz}$, $\left.\mathrm{CDCl}_{3}\right)$ : $174.56,170.73,170.66,79.80,75.34,70.72,69.21,61.94$, 51.46, 47.23, 44.97, 43.32, 41.06, 37.64, 35.51, 34.76, 34.56, 34.49, $31.34,30.75,30.64,28.9,27.28,27.08,25.51,22.69,22.54,21.63$, 21.47, 17.37, 12.11. MS-CI $\left.(\mathrm{m} / \mathrm{z}(\%)): 551[\mathrm{M}+\mathrm{H})^{+},(10)\right], 490$ (10), 430 (100), 368 (10), 340 (2), 277 (2), 214 (5), 188 (5), 154 (5), $123(5)$

Methyl 3 $\alpha$-(2-Azidoethoxy),7 $\alpha, 12 \alpha$-diacetoxy-5 $\beta$-cholan-24oate (17). A solution of alcohol 16 (Scheme 1) (302.5 mg, 0.55 mmol $)$ in dry pyridine $(9 \mathrm{~mL})$ was cooled to $0{ }^{\circ} \mathrm{C}, \mathrm{MsCl}(64 \mu \mathrm{L}$, $0.83 \mathrm{mmol}$ ) was added, and the resulting mixture was stirred for 1 $\mathrm{h}$ at $0{ }^{\circ} \mathrm{C}$. The reaction mixture was diluted with EtOAc, layers were separated, and the organic layer was washed with dilute $\mathrm{HCl}$. The organic layer was washed with brine, and dried over anhydrous $\mathrm{Na}_{2} \mathrm{SO}_{4}$. Solvent was removed under reduced pressure, and the residual oil was dissolved in DMF $(9 \mathrm{~mL})$, followed by the addition of $\mathrm{NaN}_{3}(357.3,5.5 \mathrm{mmol})$. The mixture was stirred for $24 \mathrm{~h}$ at 50 ${ }^{\circ} \mathrm{C}$, then it was cooled to room temperature, diluted with EtOAc, and isolated by $\mathrm{SiO}_{2}$ column chromatography: dry-flash, eluent hexane/EtOAc $=8: 2$. Yield $277 \mathrm{mg}(88 \%), \mathrm{mp}=101-102{ }^{\circ} \mathrm{C}$ (ether/hexane). $[\alpha]^{20}{ }_{\mathrm{D}}=+54.17\left(c=1.44, \mathrm{CH}_{2} \mathrm{Cl}_{2}\right)$. IR $(\mathrm{KBr}$ or film): $2941 \mathrm{~s}, 2870 \mathrm{~s}, 2103 \mathrm{~s}, 1735 \mathrm{~s}, 1442 \mathrm{~m}, 1376 \mathrm{~s}, 1247 \mathrm{~s}, 1199 \mathrm{w}$ $1116 \mathrm{~m}, 1023 \mathrm{~m}, 968 \mathrm{w}, 939 \mathrm{w}, 904 \mathrm{w}, 736 \mathrm{w} \mathrm{cm}{ }^{-1}$. ${ }^{1} \mathrm{H}$ NMR $(200$ $\mathrm{MHz}, \mathrm{CDCl}_{3}$ ): 5.07 (bs, $\left.\mathrm{H}-\mathrm{C}(12)\right), 4.94-4.86$ (m, H-C(7)), 3.74$3.60\left(\mathrm{~m}, \mathrm{CH}_{3} \mathrm{O}_{2} \mathrm{C}\right.$ and $\left.\mathrm{N}_{3}-\mathrm{CH}_{2}-\mathrm{CH}_{2}-\mathrm{O}\right), 3.40-3.50\left(\mathrm{~m}, \mathrm{~N}_{3}-\right.$ $\mathrm{CH}_{2}-\mathrm{CH}_{2}-\mathrm{O}$ ), 3.24-3.08 (m, $\mathrm{H}-\mathrm{C}(3)$ ), 2.12 (s, $\mathrm{CH}_{3} \mathrm{COO}-$ ), 2.08 (s, $\left.\mathrm{CH}_{3} \mathrm{COO}-\right), 0.91\left(\mathrm{~s}, \mathrm{H}_{3} \mathrm{C}-\mathrm{C}(10)\right), 0.81\left(\mathrm{~d}, J=6.2, \mathrm{H}_{3} \mathrm{C}-\right.$ $\mathrm{C}(20)), 0.72\left(\mathrm{~s}, \mathrm{H}_{3} \mathrm{C}-\mathrm{C}(13)\right) .{ }^{13} \mathrm{C}$ NMR $\left(50 \mathrm{~Hz}, \mathrm{CDCl}_{3}\right): 174.56$, $170.75,79.84,75.32,70.72,66.99,51.47,50.85,47.27,44.99,43.3$, 41.04, 37.71, 35.42, 34.78, 34.52, 31.32, 30.79, 30.68, 28.86, 27.18, 27.09, 25.47, 22.72, 22.52, 21.54, 21.41, 17.41, 12.13. MS-EI $(\mathrm{m} / \mathrm{z}$ (\%)): $\left.575[\mathrm{M}+\mathrm{H})^{+},(10)\right], 551(2), 488(25), 455(25), 428(20)$, 369 (75), 253 (50), 228 (10), 200 (25), 157 (30), 133 (25), 72 (50), $43(100)$

2-(Methyl 7 $\alpha, 12 \alpha$-diacetoxy-5 $\beta$-cholan-24-oate,3 $\alpha$-yloxy)ethanamine (18). Azide 17 (Scheme 1) (134 mg, $0.24 \mathrm{mmol}$ ) and $\mathrm{PPh}_{3}$ (72.4 mg, $0.28 \mathrm{~mol}$ ) were dissolved in THF (4 mL) followed by the addition of $\mathrm{H}_{2} \mathrm{O}(4.97 \mu \mathrm{L})$. The mixture was stirred for $24 \mathrm{~h}$ at $50{ }^{\circ} \mathrm{C}$, the solvent was removed under reduced pressure, and product was isolated by $\mathrm{SiO}_{2}$ column chromatography: dry-flash, $2 \times 10$ mL EtOAc, $8 \times 10$ mL EtOAc:MeOH:NH $\mathrm{NH}_{3}$ conc. $(18: 1: 1), 8 \times 10$ mL EtOAc:MeOH:NH $\mathrm{NH}_{3}$ conc. (18:1:1). Yield $100.3 \mathrm{mg}(81 \%)$. Colorless foam softness at $71-79^{\circ} \mathrm{C}$. $[\alpha]^{20}{ }_{\mathrm{D}}=+56.13(c=1.55$, $\mathrm{CH}_{2} \mathrm{Cl}_{2}$ ). IR (film): $3513 \mathrm{w}, 3383 \mathrm{w}, 2951 \mathrm{~s}, 2869 \mathrm{~m}, 1734 \mathrm{~s}, 1442 \mathrm{w}$, $1377 \mathrm{~m}, 1248 \mathrm{~s}, 1199 \mathrm{w}, 1101 \mathrm{~m}, 1024 \mathrm{~m}, 966 \mathrm{w}, 939 \mathrm{w}, 900 \mathrm{w}, 859 \mathrm{w}$, 736w, 700w cm ${ }^{-1}$. ${ }^{1} \mathrm{H}$ NMR (200 $\left.\mathrm{MHz}, \mathrm{CDCl}_{3}\right)$ : 5.07 (bs, $\mathrm{H}-\mathrm{C}(12)), 4.92-4.84(\mathrm{~m}, \mathrm{H}-\mathrm{C}(7)), 3.66\left(\mathrm{~s}, \mathrm{CH}_{3} \mathrm{O}_{2} \mathrm{C}\right), 3.56-3.42$ $\left(\mathrm{m}, \mathrm{H}_{2} \mathrm{~N}-\mathrm{CH}_{2}-\mathrm{CH}_{2}-\mathrm{O}\right), 3.18-3.00(\mathrm{~m}, \mathrm{H}-\mathrm{C}(3)), 2.90-2.80(\mathrm{~m}$, $\mathrm{H}_{2} \mathrm{~N}-\mathrm{CH}_{2}-\mathrm{CH}_{2}-\mathrm{O}$ ), 2.13 (s, $\mathrm{CH}_{3} \mathrm{COO}-$ ), 2.08 (s, $\mathrm{CH}_{3} \mathrm{COO}-$ ), $0.90\left(\mathrm{~s}, \mathrm{H}_{3} \mathrm{C}-\mathrm{C}(10)\right), 0.80\left(\mathrm{~d}, J=6.2, \mathrm{H}_{3} \mathrm{C}-\mathrm{C}(20)\right), 0.72\left(\mathrm{~s}, \mathrm{H}_{3} \mathrm{C}-\right.$ $\mathrm{C}(13)) .{ }^{13} \mathrm{C}$ NMR $\left(50 \mathrm{~Hz}, \mathrm{CDCl}_{3}\right): 174.54,170.68,79.66,75.36$, 70.74, 70.41, 51.44, 47.23, 44.97, 43.34, 42.02, 41.11, 37.67, 35.58, $34.85,34.58,34.49,31.35,30.77,30.66,28.92,27.38,27.08,25.53$, $22.69,22.56,21.61,21.47,17.37,12.11$. MS-EI $(\mathrm{m} / \mathrm{z}(\%)): 550$ $\left.[\mathrm{M}+\mathrm{H})^{+},(50)\right], 490(10), 458(10), 412(5), 387$ (5), $353(10)$, 314 (10), 253 (50), 213 (10), 173 (25), 145 (25), 95 (75), 46 (100).

BoNT/A LC Metalloprotease Activity. The assay to determine BoNT/A LC metalloprotease activity was performed as previously described. ${ }^{34,53-55}$ Percent inhibition measurements were performed in duplicate, and in all cases standard deviations were less than $\pm 25 \%$. $\mathrm{IC}_{50}$ values for the SMNPIs were calculated from plots of concentration versus inhibition using seven concentrations each (1 and 2) or nine concentrations each (3 and 4). ${ }^{56}$ Results are the averages of duplicate determinations.

Molecular Modeling. Insight II (Accelrys, San Diego, CA) was used to build and visualize models on a Silicon Graphics Octane 2. Energy refinements were carried out with the Discover program (Accelrys, San Diego, CA) and the CFF91 forcefield (implemented through Insight II). The HINT (hydropathic interactions) program (eduSoft, Richmond, VA) (also implemented through Insight II) 
was used to evaluate model quality based on the quantitation of intra- and intermolecular contacts. ${ }^{57}$ HINT parameters were set with the steric term $=$ Lennard-Jones 6-9 (for CFF91 compatibility); lone pair vector focusing $=10$; and distance dependence atomatom interactions $=\exp (-1 / r)$.

A dynamic conformer ${ }^{33}$ taken from a trajectory of PDB ref code $1 \mathrm{E} 1 \mathrm{H}^{58}$ was used for enzyme coordinates. Inhibitors $\mathbf{1}-\mathbf{4}$ were docked using our hydrophobicity first rule, ${ }^{33}$ which involves characterizing inhibitor components on the basis of their hydrophobicity and polarity. ${ }^{33}$ Identifying complementary binding surfaces for the most hydrophobic components of the inhibitor is prioritized, followed by the identification of complementary contacts for polar components. This results in a minimization of unfavorable intermolecular contacts (hydrophobic-polar, base-base, acid$\operatorname{acid}^{57}$ ) and maximizes favorable interactions (hydrophobichydrophobic, hydrogen bonds, and acid-base ${ }^{57}$ ).

Translational, rotational, and torsional adjustments were performed when docking the inhibitors, while, at the same time, torsional adjustments to enzyme residue side chains (within defined limits of rotamer libraries) were also examined. A van der Waals bump of $0.25 \AA$ was used to remove unacceptably close atomatom contacts. A described tethered minimization strategy was used during model refinement. ${ }^{31-33,57,59,60}$ The strategy involved the application of $2000 \mathrm{kcal} / \mathrm{mol}$ per $\AA^{2}$ of force that was stepped off the inhibitor-enzyme model in $100 \mathrm{kcal} / \mathrm{mol}$ decrements via minimization with conjugate gradients (until the norm of the gradient was $0.001 \mathrm{kcal} / \AA \AA$ ). This process was repeated until all external force was removed. Following, inter- and intramolecular analyses of the docked inhibitor were again examined using the HINT program, ${ }^{57}$ and unfavorable interactions were removed using rounds of manual adjustments (translational, rotational, and torsional) and tethered minimizations. Cycles of HINT analyses, manual adjustments, and tethered energy minimizations were performed until biochemically reasonable binding models were obtained.

The program Catalyst 4.7 (Accelrys, San Diego, CA) was used to map pharmacophore components to inhibitors. Figures $2-4$ were generated using Insight II; Figure 1 was generated using Catalyst 4.7.

Acknowledgment. This research was supported by Defense Threat Reduction Agency 3.10024_06_RD_B, to S. Bavari, the United States Army Medical Research and Material Command, and IAA Y3 CM 100505 (MRMC and NCI, National Institutes of Health). This project has been funded in whole or in part with federal funds from the National Cancer Institute, National Institutes of Health, under contract N01-CO-12400. The content of this publication does not necessarily reflect the views or policies of the Department of Health and Human Services, nor does mention of trade names, commercial products, or organizations imply endorsement by the U.S. Government or the U.S. Army. This research was supported [in part] by the Developmental Therapeutics Program in the Division of Cancer Treatment and Diagnosis of the National Cancer Institute. We are grateful to, thank, and acknowledge the Ministry of Science, Technologies and Development of Serbia for financial support (Grant No. 142022). We acknowledge the allocation of computing time and staff support at the Advanced Biomedical Computing Center of the Frederick Cancer Research and Development Center.

Supporting Information Available: Spectroscopic data for synthesized/isolated compounds. This material is available free of charge via the Internet at http://pubs.acs.org.

\section{References}

(1) Arnon, S. S.; Schechter, R.; Inglesby, T. V.; Henderson, D. A.; Bartlett, J. G.; Ascher, M. S.; Eitzen, E.; Fine, A. D.; Hauer, J.; Layton, M.; Lillibridge, S.; Osterholm, M. T.; O’Toole, T.; Parker, G.; Perl, T. M.; Russell, P. K.; Swerdlow, D. L.; Tonat, K. Botulinum toxin as a biological weapon: medical and public health management. JAMA, J. Am. Med. Assoc. 2001, 285, 1059-70.

(2) Paddle, B. M. Therapy and prophylaxis of inhaled biological toxins. J. Appl. Toxicol. 2003, 23, 139-70.

(3) Burnett, J. C.; Henchal, E. A.; Schmaljohn, A. L.; Bavari, S. The evolving field of biodefence: therapeutic developments and diagnostics. Nat. Rev. Drug Discovery 2005, 4, 281-297.

(4) Clarke, S. C. Bacteria as potential tools in bioterrorism, with an emphasis on bacterial toxins. Br. J. Biomed. Sci. 2005, 62, 40-6.

(5) Hicks, R. P.; Hartell, M. G.; Nichols, D. A.; Bhattacharjee, A. K. van Hamont, J. E.; Skillman, D. R. The medicinal chemistry of botulinum, ricin and anthrax toxins. Curr. Med. Chem. 2005, 12, 667-90.

(6) Josko, D. Botulin toxin: a weapon in terrorism. Clin. Lab. Sci. 2004, 17, 30-4.

(7) Bhidayasiri, R.; Truong, D. D. Expanding use of botulinum toxin. $J$. Neurol. Sci. 2005, 235, 1-9.

(8) Bigalke, H.; Rummel, A. Medical aspects of toxin weapons. Toxicology 2005, 214, 210-220.

(9) Comella, C. L.; Pullman, S. L. Botulinum toxins in neurological disease. Muscle Nerve 2004, 29, 628-44.

(10) Foster, K. A. A new wrinkle on pain relief: re-engineering clostridial neurotoxins for analgesics. Drug Discovery Today 2005, 10, 5639.

(11) Glogau, R. G. Review of the use of botulinum toxin for hyperhidrosis and cosmetic purposes. Clin. J. Pain 2002, 18 (6 Suppl), S191-7.

(12) Marks, J. D. Medical aspects of biologic toxins. Anesthesiol. Clin. North Am. 2004, 22, 509-32, vii.

(13) Montecucco, C.; Molgo, J. Botulinal neurotoxins: revival of an old killer. Curr. Opin. Pharmacol. 2005, 5, 274-9.

(14) Shukla, H. D.; Sharma, S. K. Clostridium botulinum: a bug with beauty and weapon. Crit. Rev. Microbiol. 2005, 31, 11-8.

(15) Cote, T. R.; Mohan, A. K.; Polder, J. A.; Walton, M. K.; Braun, M. M. Botulinum toxin type A injections: adverse events reported to the US Food and Drug Administration in therapeutic and cosmetic cases. J. Am. Acad. Dermatol. 2005, 53, 407-15.

(16) Black, R. E.; Gunn, R. A. Hypersensitivity reactions associated with botulinal antitoxin. Am. J. Med. 1980, 69, 567-70.

(17) Martin, C. O.; Adams, H. P., Jr. Neurological aspects of biological and chemical terrorism: a review for neurologists. Arch. Neurol. 2003, 60, 21-5.

(18) Eleopra, R.; Tugnoli, V.; Rossetto, O.; De Grandis, D.; Montecucco, C. Different time courses of recovery after poisoning with botulinum neurotoxin serotypes A and E in humans. Neurosci. Lett. 1998, 256, $135-8$.

(19) Meunier, F. A.; Lisk, G.; Sesardic, D.; Dolly, J. O. Dynamics of motor nerve terminal remodeling unveiled using SNARE-cleaving botulinum toxins: the extent and duration are dictated by the sites of SNAP-25 truncation. Mol. Cell. Neurosci. 2003, 22, 454-66.

(20) Singh, B. R. Intimate details of the most poisonous poison. Nat. Struct. Biol. 2000, 7, 617-9.

(21) Turton, K.; Chaddock, J. A.; Acharya, K. R. Botulinum and tetanus neurotoxins: structure, function and therapeutic utility. Trends Biochem. Sci. 2002, 27, 552-8.

(22) Binz, T.; Blasi, J.; Yamasaki, S.; Baumeister, A.; Link, E.; Sudhof, T. C.; Jahn, R.; Niemann, H. Proteolysis of SNAP-25 by types E and A botulinal neurotoxins. J. Biol. Chem. 1994, 269, 1617-20.

(23) Schmidt, J. J.; Stafford, R. G. Botulinum neurotoxin serotype F: identification of substrate recognition requirements and development of inhibitors with low nanomolar affinity. Biochemistry 2005, 44, 4067-73.

(24) Schiavo, G.; Benfenati, F.; Poulain, B.; Rossetto, O.; Polverino de Laureto, P.; DasGupta, B. R.; Montecucco, C. Tetanus and botulinum-B neurotoxins block neurotransmitter release by proteolytic cleavage of synaptobrevin. Nature 1992, 359, 832-5.

(25) Schiavo, G.; Malizio, C.; Trimble, W. S.; Polverino de Laureto, P.; Milan, G.; Sugiyama, H.; Johnson, E. A.; Montecucco, C. Botulinum $\mathrm{G}$ neurotoxin cleaves VAMP/synaptobrevin at a single Ala-Ala peptide bond. J. Biol. Chem. 1994, 269, 20213-6.

(26) Schiavo, G.; Rossetto, O.; Catsicas, S.; Polverino de Laureto, P.; DasGupta, B. R.; Benfenati, F.; Montecucco, C. Identification of the nerve terminal targets of botulinum neurotoxin serotypes A, D, and E. J. Biol. Chem. 1993, 268, 23784-7.

(27) Schiavo, G.; Shone, C. C.; Rossetto, O.; Alexander, F. C.; Montecucco, C. Botulinum neurotoxin serotype $\mathrm{F}$ is a zinc endopeptidase specific for VAMP/synaptobrevin. J. Biol. Chem. 1993, 268, 11516- 
(28) Blasi, J.; Chapman, E. R.; Yamasaki, S.; Binz, T.; Niemann, H.; Jahn, $\mathrm{R}$. Botulinum neurotoxin $\mathrm{C} 1$ blocks neurotransmitter release by means of cleaving HPC-1/syntaxin. EMBO J. 1993, 12, 4821-8.

(29) Lacy, D. B.; Tepp, W.; Cohen, A. C.; DasGupta, B. R.; Stevens, R. C. Crystal structure of botulinum neurotoxin type A and implications for toxicity. Nat. Struct. Biol. 1998, 5, 898-902.

(30) Swaminathan, S.; Eswaramoorthy, S. Structural analysis of the catalytic and binding sites of Clostridium botulinum neurotoxin B. Nat. Struct. Biol. 2000, 7, 693-9.

(31) Burnett, J. C.; Schmidt, J. J.; Stafford, R. G.; Panchal, R. G.; Nguyen, T. L.; Hermone, A. R.; Vennerstrom, J. L.; McGrath, C. F.; Lane, D. J.; Sausville, E. A.; Zaharevitz, D. W.; Gussio, R.; Bavari, S. Novel small molecule inhibitors of botulinum neurotoxin A metalloprotease activity. Biochem. Biophys. Res. Commun. 2003, 310, 8493.

(32) Burnett, J. C.; Schmidt, J. J.; McGrath, C. F.; Nguyen, T. L.; Hermone, A. R.; Panchal, R. G.; Vennerstrom, J. L.; Kodukula, K.; Zaharevitz, D. W.; Gussio, R.; Bavari, S. Conformational sampling of the botulinum neurotoxin serotype A light chain: implications for inhibitor binding. Bioorg. Med. Chem. 2005, 13, 333-41.

(33) Burnett, J. C.; Ruthel, G.; Stegmann, C. M.; Panchal, R. G.; Nguyen, T. L.; Hermone, A. R.; Stafford, R. G.; Lane, D. J.; Kenny, T. A.; McGrath, C. F.; Wipf, P.; Stahl, A. M.; Schmidt, J. J.; Gussio, R.; Brunger, A. T.; Bavari, S. Inhibition of metalloprotease botulinum serotype A: from a pseudo-peptide binding mode to a small molecule that is active in primary neurons. J. Biol. Chem. 2007, 282, 500414.

(34) Schmidt, J. J.; Stafford, R. G. A high-affinity competitive inhibitor of type A botulinum neurotoxin protease activity. FEBS Lett. 2002 $532,423-6$.

(35) Deshpande, S. S.; Sheridan, R. E.; Adler, M. Efficacy of certain quinolines as pharmacological antagonists in botulinum neurotoxin poisoning. Toxicon 1997, 35, 433-45.

(36) Sheridan, R. E.; Deshpande, S. S.; Nicholson, J. D.; Adler, M. Structural features of aminoquinolines necessary for antagonist activity against botulinum neurotoxin. Toxicon 1997, 35, 1439-51.

(37) Hawley, S. R.; Bray, P. G.; Park, B. K.; Ward, S. A. Amodiaquine accumulation in Plasmodium falciparum as a possible explanation for its superior antimalarial activity over chloroquine. Mol. Biochem. Parasitol. 1996, 80, 15-25.

(38) Vippagunta, S. R.; Dorn, A.; Matile, H.; Bhattacharjee, A. K.; Karle, J. M.; Ellis, W. Y.; Ridley, R. G.; Vennerstrom, J. L. Structural specificity of chloroquine-hematin binding related to inhibition of hematin polymerization and parasite growth. J. Med. Chem. 1999, 42, 4630-9.

(39) Vippagunta, S. R.; Dorn, A.; Ridley, R. G.; Vennerstrom, J. L. Characterization of chloroquine-hematin mu-oxo dimer binding by isothermal titration calorimetry. Biochim. Biophys. Acta 2000, 1475, 133-40.

(40) Boldt, G. E.; Kennedy, J. P.; Janda, K. D. Identification of a potent botulinum neurotoxin A protease inhibitor using in situ lead identification chemistry. Org. Lett. 2006, 8, 1729-32.

(41) Merino, I.; Thompson, J. D.; Millard, C. B.; Schmidt, J. J.; Pang, Y. $\mathrm{P}$. Bis-imidazoles as molecular probes for peripheral sites of the zinc endopeptidase of botulinum neurotoxin serotype A. Bioorg. Med. Chem. 2006, 14, 3583-3591.

(42) Park, J. G.; Sill, P. C.; Makiyi, E. F.; Garcia-Sosa, A. T.; Millard, C. B.; Schmidt, J. J.; Pang, Y. P. Serotype-selective, small-molecule inhibitors of the zinc endopeptidase of botulinum neurotoxin serotype A. Bioorg. Med. Chem. 2006, 14, 395-408.

(43) Vennerstrom, J. L.; Ellis, W. Y.; Ager, A. L., Jr.; Andersen, S. L.; Gerena, L.; Milhous, W. K. Bisquinolines. 1. N,N-bis(7-chloroquinolin-4-yl)alkanediamines with potential against chloroquine-resistant malaria. J. Med. Chem. 1992, 35, 2129-34.

(44) Fried, J. E.; Edwards, J. A. Organic Reactions in Steroid Chemistry; van Nostrand Reinhold Co.: New York, 1972; Vol. I, pp 75-81 and refs therein.
(45) Musonda, C. C.; Gut, J.; Rosenthal, P. J.; Yardley, V.; Carvalho de Souza, R. C.; Chibale, K. Application of multicomponent reactions to antimalarial drug discovery. Part 2: New antiplasmodial and antitrypanosomal 4-aminoquinoline gamma- and delta-lactams via a 'catch and release' protocol. Bioorg. Med. Chem. 2006, 14, 560515 .

(46) Albert, D.; Feigel, M. Beta-loop, gamma-loop and helical peptide conformations in cyclopeptides containing a steroidal pseudo-amino acid. Helv. Chim. Acta 1997, 80, 2168-2181.

(47) Peck, R. M.; Preston, R. K.; Creech, H. J. Nitrogen mustard analogs of animalarial drugs. J. Am. Chem. Soc. 1958, 81, 39843989.

(48) Price, C. C.; Leonard, N. J.; Peel, E. W.; Reitsem, R. H. Some 4-amino-7-chloroquinoline derivatives. J. Am. Chem. Soc. 1946, 68 1807-1808.

(49) Singh, C.; Malik, H.; Puri, S. K. Synthesis and antimalarial activity of a new series of trioxaquines. Bioorg. Med. Chem. 2004, 12, 117782.

(50) Kanth, J. V. B.; Periasamy, M. Selective reduction of carboxylic acids into alcohols using $\mathrm{NaBH}_{4}$, and $\mathrm{I}_{2}$. J. Org. Chem. 1991, 56, 59645965.

(51) Opsenica, D.; Pocsfalvi, G.; Juranic, Z.; Tinant, B.; Declercq, J. P.; Kyle, D. E.; Milhous, W. K.; Solaja, B. A. Cholic acid derivatives as 1,2,4,5-tetraoxane carriers: structure and antimalarial and antiproliferative activity. J. Med. Chem. 2000, 43, 3274-82.

(52) Wess, G. K. W.; Bartmann, W.; Enhasen, A.; Glombik, H.; Mullner, S.; Bock, K.; Dries, A.; Kleine, H.; Schmitt, W. Modified bile acids: preparation of $7 \alpha, 12 \alpha$-dihydroxy- $3 \beta$ - and $7 \alpha, 12 \alpha$-dihydroxy$3 \alpha$ (2-hyroxyethoxy)-5 $\beta$-cholanic acid and their biological activity. Tetrahedron Lett. 1992, 33, 195-198.

(53) Schmidt, J. J.; Bostian, K. A. Proteolysis of synthetic peptides by type A botulinum neurotoxin. J. Protein Chem. 1995, 14, 703-8

(54) Schmidt, J. J.; Bostian, K. A. Endoproteinase activity of type A botulinum neurotoxin: substrate requirements and activation by serum albumin. J. Protein Chem. 1997, 16, 19-26.

(55) Schmidt, J. J.; Stafford, R. G.; Bostian, K. A. Type A botulinum neurotoxin proteolytic activity: development of competitive inhibitors and implications for substrate specificity at the $\mathrm{S} 1^{\prime}$ binding subsite. FEBS Lett. 1998, 435, 61-4.

(56) Segel, I. H. Enzyme Kinetics; Wiley: New York, 1975; pp 109111.

(57) Nguyen, T. L.; McGrath, C.; Hermone, A. R.; Burnett, J. C.; Zaharevitz, D. W.; Day, B. W.; Wipf, P.; Hamel, E.; Gussio, R. A common pharmacophore for a diverse set of colchicine site inhibitors using a structure-based approach. J. Med. Chem. 2005, 48, 610716.

(58) Segelke, B.; Knapp, M.; Kadkhodayan, S.; Balhorn, R.; Rupp, B. Crystal structure of Clostridium botulinum neurotoxin protease in a product-bound state: Evidence for noncanonical zinc protease activity. Proc. Natl. Acad. Sci. U.S.A. 2004, 101, 6888-93.

(59) Gussio, R.; Zaharevitz, D. W.; McGrath, C. F.; Pattabiraman, N.; Kellogg, G. E.; Schultz, C.; Link, A.; Kunick, C.; Leost, M.; Meijer, L.; Sausville, E. A. Structure-based design modifications of the paullone molecular scaffold for cyclin-dependent kinase inhibition. Anti-Cancer Drug Des. 2000, 15, 53-66.

(60) Panchal, R. G.; Hermone, A. R.; Nguyen, T. L.; Wong, T. Y.; Schwarzenbacher, R.; Schmidt, J.; Lane, D.; McGrath, C.; Turk, B. E.; Burnett, J.; Aman, M. J.; Little, S.; Sausville, E. A.; Zaharevitz, D. W.; Cantley, L. C.; Liddington, R. C.; Gussio, R.; Bavari, S. Identification of small molecule inhibitors of anthrax lethal factor. Nat. Struct. Mol. Biol. 2004, 11, 67-72.

JM061446E 